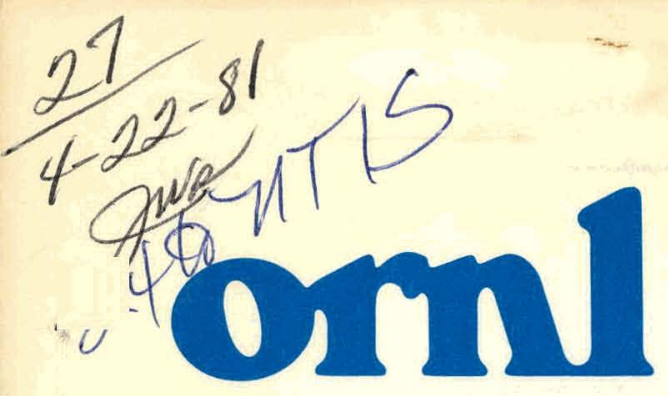

OAK RIDGE NATIONAL LABORATORY

\section{UNION CARBIDE}

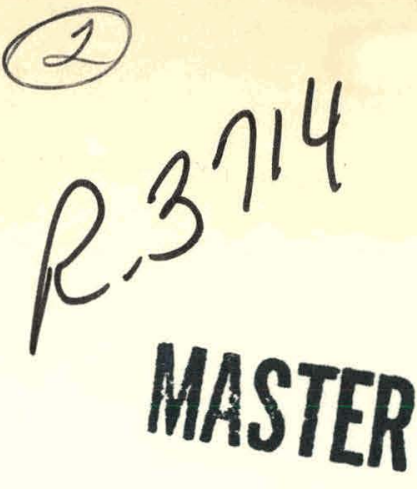

ORNL/TM-7412

\title{
An Approach to Ecological Assessment of Power-Plant- Intake (316b) Related Issues: The Prairie Island Case
}

\author{
S. M. Adams \\ D. S. Vaughan \\ S. G. Hildebrand \\ K. D. Kumar
}

\section{ENVIRONMENTAL SCIENCES DIVISION Publication No. 1557}

OPERATED BY

UNION CARBIDE CORPORATION FOR THE UNITED STATES DEPARTMENT OF ENERGY

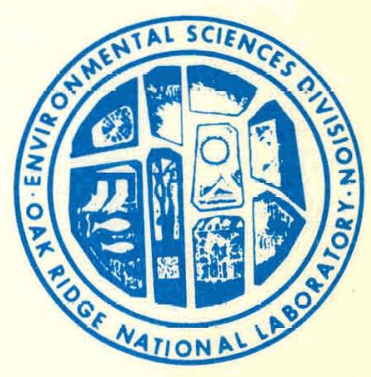




\section{DISCLAIMER}

This report was prepared as an account of work sponsored by an agency of the United States Government. Neither the United States Government nor any agency Thereof, nor any of their employees, makes any warranty, express or implied, or assumes any legal liability or responsibility for the accuracy, completeness, or usefulness of any information, apparatus, product, or process disclosed, or represents that its use would not infringe privately owned rights. Reference herein to any specific commercial product, process, or service by trade name, trademark, manufacturer, or otherwise does not necessarily constitute or imply its endorsement, recommendation, or favoring by the United States Government or any agency thereof. The views and opinions of authors expressed herein do not necessarily state or reflect those of the United States Government or any agency thereof. 


\section{DISCLAIMER}

Portions of this document may be illegible in electronic image products. Images are produced from the best available original document. 


\section{Printed in the United States of America. Available from National Technical Information Service \\ U.S. Department of Commerce 5285 Port Royal Road, Springfield, Virginia 22161 NTIS price codes-Printed Copy: A06; Microfiche A01}

This report was prepared as an account of work sponsored by an agency of the United States Government. Neither the United States Government nor any agency thereof, nor any of their employees, makes any warranty, express or implied, or assumes any legal liability or responsibility for the accuracy, completeness, or usefulness of any information, apparatus, product, or process disclosed, or represents that its use would not infringe privately owned rights. Reference herein to any specific commercial product, process, or service by trade name, trademark, manufacturer, or otherwise, does not necessarily constitute or imply its endorsement, recommendation, or favoring by the United States Government or any agency thereof. The views and opinions of authors expressed herein do not necessarily state or reflect those of the United States Government or any agency thereof. 
Contract No. W-7405-eng-26

AN APPROACH TO ECOLOGICAL ASSESSMENT OF POWER-PLANT-INTAKE (316b) RELATED ISSUES: THE PRAIRIE ISLAND CASE

S. M. Adams, D. S. Vaughan, S. G. Hildebrand, and K. D. Kumar

\section{ENVIRONMENTAL SCIENCES DIVISION}

Publication No. 1557

Date Published - April 1981

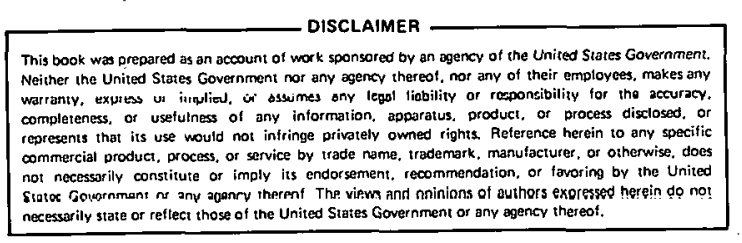

OAK RIDGE NATIONAL LABORATORY

Oak Ridge, Tennessee operated by

UNION CARBIDE CORPORATION

for the

DEPARTMENT OF ENERGY 
THIS PAGE

\section{WAS INTENTIONALLY LEFT BLANK}




\section{ACKNOWLEDGEMENTS}

This study was supported under contract with the Minnesota Pollution Control Agency with cooperation of the U.S. Environmental Protection Agency, Region V. The authors express their appreciation to Gary Milburn of EPA-Region $V$ for his helpful advice during the study. Also, we are grateful to S. W. Christensen, R. B. McLean, and W. Van Winkle of the Environmental Sciences Division of Oak Ridge National Laboratory, for their critical review of the manuscript. 


\section{$\ldots$ THIS PAGE \\ WAS INTENTIONALLY \\ LEFT BLANK}




\section{ABSTRACT}

ADAMS, S. M., D. S. VAUGHAN, S. G. HILDEBRAND, and K. D. KUMAR. 1981. An approach to ecological assessment of powerplant-intake (316b) related issues: The Prairie Island case. ORNL/TM-7412. Oak Ridge National Laboratory, Oak Ridge, Tennessee. $102 \mathrm{pp}$.

Assessment approaches and strategies useful in addressing important issues in section $316(b)$ of the 1972 Federal Water Pollution Control Act are illustrated in this report through the analysis and evaluation of the Prairie Island Nuclear Station 316(b) data base.

The main issues in $316(\mathrm{~b})$ demonstrations, cooling water intake operation and location, involve determining the impacts of entrainment and impingement. Entrainment impacts were addressed by applying the "equivalent adult" approach and correcting for inherent biases and by determining the through-plant survival of zooplankton. An assessment of impingement impacts was made by comparing for each of various species the number of fish impinged to estimates of population size.

Densities of plankton and fish were compared between the intake area and an alternate area to determine if the location of the present intake minimizes impacts. No definitive conclusion relative to the best location of the intake could be made hecause of high year to year variability in the data and the differential dominance of trophic groups between areas. 
THIS PAGE

WAS INTENTIONALLY

LEFT BLANK 
TABLE OF CONTENTS

Page

ABSTRACT . . . . . . . .............. . v v

LIST OF TABLES . . . . . . . . . . . . . . . . . . . $\quad \mathrm{ix}$

LIST OF FIGURES . . . . . . . . . . . . . . . . . xiii

INTRODUCTION . . . . . . . . . . . . . . . . . . 1

SITE AND PLANT DESCRIPTION . . . . . . . . . . . . . . . 2

OPERATIONAL IMPACTS OF THE PRESENT INTAKE SYSTEM . . . . . . . . . 5

Entrainment Issues ................ 5

Entrainment Impacts on Adult Fish . . . . . . . . . 6

Estimation of daily concentration . . . . . . . 7

Gear avoidance . . . . . . . . . . . . . . 9

Age of entrained life stages ............ 11

Identification problems . . . . . . . . . . 17

Fecundity and resultant projections . . . . . . . 19

ENTRAINMENT SURVIVAL OF PLANKTON . . . . . . . . . 32

IMPINGEMENT CONSIDERATIONS . . . . . . . . . . . 47

ALTERNATIVE INTAKE LOCATIONS . . . . . . . . . . . . . 50

Phytoplankton .................. . . 51

Primary Productivity . . . . . . . . . . . . 56

Zooplankton .................. . . 57

Fish . . . . . . . . . . . . . . . . . 62

Ichthyoplankton ...................... 66

Results of stations I and III comparisons . . . . . . 67

Discussion . . . . . . . . . . . . . . . . 70 
Page

Results of stations I, II, III comparisons . . . . . 74

Surmary ............... . 76

Alternative location summary . . . . . . 79

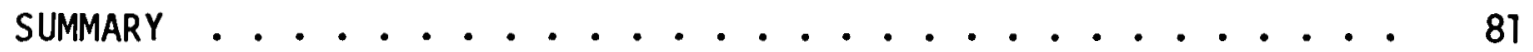

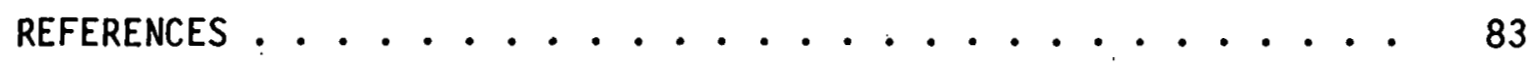




\section{LIST OF TABLES}

$\underline{T a b l e}$

Page

1 Number of samples and sampling volumes at the bar rack station in 1975 by day and night for each sampling date at Prairie Island Nuclear Generating Plant . . . . .

2 Estimates of daily larval concentrations (\#/m $\left.\mathrm{m}^{3}\right)$ at the bar rack station in 1975 based on day and night samples and the total estimated numbers of larvae and juveniles entrained $\left(N_{l}\right)$ at

Prairie Island Nuclear Generating Plant . . . . . . . .

3 Estimates of daily larval concentrations $\left(\# / \mathrm{m}^{3}\right)$ at the bar rack station in 1975 based on night samples and the total estimated numbers of larvae and juveniles entrained $\left(\mathrm{N}_{l}\right)$ at Prairie Island Nuclear Generating Plant . . . . . . . . . . . .

4 Estimated survival from the protolarval stage to the indicated stage in 1975 at Prairie Island Nuclear Generating Plant.................

5 Entrainment by life stage at the bar rack station in 1975 using night samples

6 Adjustment for identification problem in 1975 at the bar rack station at Prairie Island Nuclear Generating Plant ..................

7 Estimated survival to adulthood, $S$, based on age-specific fecundities for five fish species as a function of adult survivability, calculated using

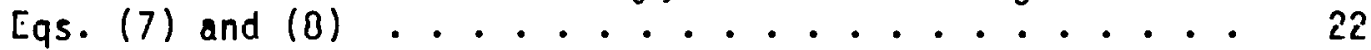

8 Calculation of "equivalent adults" lost due to the entrainment of fish eggs, larvae and juveniles in 1975 at Prairie Island Nuclear Generating Plant after correcting for several sources of bias and assuming an adult annual survival rate of $0.5 . . . .$. .

9 A partial comparison of the predicted loss in "equivalent adults" between Table 6.4-1 of the 316(b) demonstration (NUS 1976) and Table 8 for 1975 at Prairie Island Nuclear Generating Plant 
10 Sample size, $n$, required to detect an underlying

through-plant mortality, $f_{c}$, of 0.25 using

Fleiss' test for differences in proportions

(one-tailed) for a range of powers, $1-\beta$, two

levels of significance, $\alpha$, and a range of

sampling survivals at the intake, $P_{I}$..........

11 Sample size, $n$, required to detect an underlying

through-plant mortality, $f_{C}$, of 0.5 using

Fleiss' test for differences in proportions

(one-tailed) for a range of powers, 1- $\beta$, two

levels of significance, $\alpha$, and a range of

sampling survivals at the intake, $P_{I}$

12 Sample size, $n$, required to detect an underlying

through-plant mortality, $f_{C}$, of 0.75 using

Fleiss' test for differences in proportions

(one-tailed) for a range of powers, $1-\beta$, two

levels of significance, $\alpha$, and a range of

sampling survivals at the intake, $P_{I}$

13 Sample size, $n$, required to detect an underlying

through-plant mortality, $f_{c}$, of 1.0 using

Fleiss' test for differences in proportions

(one-tailed) for a range of powers, ]- $\beta$, two

levels of significance, $\alpha$, and a range of

sampling survivals at the intake, $\mathrm{P}_{I}$. . . . . . . .

14 The lowest observed through-plant entrainment

mortality, $f_{c}$, detectable as significantly

greater than zero as a function of sampling

survival at the intake $\left(P_{I}\right)$ and sample size (n)

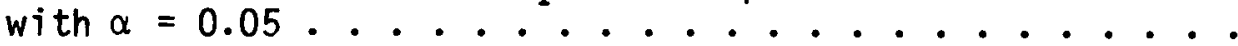

15 Daily, seasonal, and total estimated through-plant

entrainment mortality, $f_{c}$, for four categories

of zooplankton in 7974 ................

16 Daily, seasonal and total estimated through-plant

entrainment mortality, $f_{c}$, for four categories

of zooplankton in 1975-76..............

17 Sampling survival, $\mathrm{P}_{I}$, estimated by categories

and year .......................

18 Daily sample sizes at the intake (I) and

discharge (D) stations used in calculating

through-plant entrainment mortality, $f_{c}$, for

four categories of zooplankton in 1974 through

1976 at Prairie Island Nuclear Generating Plant . . . . . 
19 Number impinged, population estimates, and percent of the population impinged for the major species in the Mississippi River and Sturgeon Lake near the at Prairie Island Nuclear Generating Plant ....

20 Estimated average differences in phytoplankton density between the Mississippi River $\left(D_{r}\right)$ and Sturgeon Lake $\left(D_{S}\right)$ for 1974-1976 and all years combined ...............

21 Estimated average differences in primary productivity between the Mississippi River $\left(D_{r}\right)$ and Sturgeon Lake $\left(D_{s}\right)$ for 1974-1975 and for these years combined ........

22 Estimated average difference in zooplankton densities (weights) between the Mississippi River $\left(D_{r}\right)$ and Sturgeon Lake $\left(D_{S}\right)$ for 1974-1976 and all years combined ..........

23 Catch-per-unit-effort (Ns number per 15-min sample) by electroshocking in Sturgeon Lake (stat. 1-7) and the main river (stat. 2-9) for three months

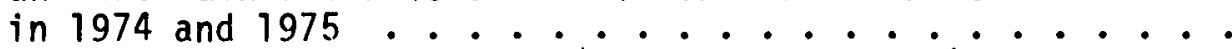

24 Number of game and nongame fish and the ratio of game fish to total fish caught at stations 1-7 (Sturgeon Lake) and 2-9 (Main River) in 1974, 1975, and for 1974 and 1975 combined ...........

25 Total number of larvae (or eggs when indicated) caught during the June 6-17 survey and the number of replicates (maximum $=24$ ) in which each category appears for each station ............

26 Analysis of variance for all larvae collected at stations I and III during June 6-17 ........

27 Analysis of variance for all eggs collected at stations I and III during June $6-17$........

28 Statistical comparison of the average larval densities between stations I and III for

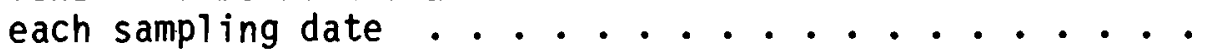

29 Statistical comparison of the larval densities (logs) between station I (river) and station III (Sturgeon Lake) for each of the ten categories of fish ................... 
30 Analysis of variance and Duncan's Multiple Range Test for all eggs collected at stations I, II, and III during June $6-17,1978$............ 75

31 Analysis of variance and Duncan's Multiple Range Test for all larvae collected at stations I-III during June $6-17,1978$. . . . . . . . . .

32 Duncan's Multiple Range Test $(\alpha=0.05)$ for the 1 arval densities (log transform) of 10 categories of fish at stations I, II, and III. Underlined stations are not significantiy different . . . . . . 78

33 Summary of results relative to the best location of the intake for minimizing impacts to various trophic groups .................. 80 


\section{LIST OF FIGURES}

\section{Figure}

1 Location of the Prairie Island Nuclear Generating Plant on the Mississippi River $65 \mathrm{~km}$ southeast of Minneapolis, Minnesota ..................

2 Minimum detectable through-plant entrainment mortality, $f_{C}$, as a function of sampling survival at the intake, $P_{I}$, and sample size, $n$, with $\alpha=0.05$

3 Temporal distribution of the differences in the natural logarithms of Sturgeon Lake $\left(D_{s}\right)$ and the Mississippi River $\left(D_{r}\right)$ phytoplankton densities . . . .

4 Temporal distribution of the differences in the natural logarithms of Sturgeon Lake $\left(D_{s}\right)$ and the Mississippi River $\left(D_{r}\right)$ zooplankton densities .....

5 Average monthly river flows of the Mississippi River at Prescott for 1974-1976 and the historical averages for $1950-1965$ 


\section{INTRODUCTION}

Section $316(b)$ of the Federal Water Pollution Control Act Amendments of 1972 requires that the location, design, construction, and operation of cooling water intake structures reflect the best technology available for minimizing adverse environmental impact. Northern States Power Company (the "applicant") has prepared a $316(b)$ demonstration in support of the intake system for the Prairie Island Nuclear Generating Plant (PINGP) located on the Mississippi River approximately $65 \mathrm{~km}$ southeast of Minneapolis/St. Paul, Minnesota. Oak Ridge National Laboratory, under a contract with the Minnesota Pollution Control Agency, conducted an independent analysis of the aquatic impacts of PINGP relative to the location, operation, design, and construction of the present and alternative intake systems (Adams et al. 1979). The purpose of this report is to present selected areas of this analysis that illustrate assessment approaches and strategies useful in addressing major $316(b)$ related issues.

This report focuses on two of the main areas of concern in $316(\mathrm{~b})$ documents: (1) environmental impacts associated with cooling water intake operation and (2) concerns related to intake location. Impacts associated with cooling water intake design and construction are, in general, more generic problems and are treated extensively in other reports (Cannon et a1. 1979, Sonnichsen et a1. 1975, Ray et a1. 1976, EPA 1976). 


\section{SITE AND PLANT DESCRIPTION}

The Prairie Island Nuclear Generating Plant is located on the Minnesota shore of the Mississippi River $65 \mathrm{~km}(40 \mathrm{mi})$ southeast of Minneapolis and St. Paul, Minnesota and $10 \mathrm{~km}$ upstream of Red Wing, Minnesota. The Mississippi River in the vicinity of PINGP is a complex system of river lakes, sloughs, channels, and islands (Fig. 1). Major features of this system include North and Sturgeon Lakes, just upstrean of the plant, and the main river channel closer to the Wisconsin shore. Lock and Dam No. 3, which controls the levels of the Mississippi River and Sturgeon Lake, is $2 \mathrm{~km}$ downstream of the site. The ecological character of the Mississippi River near PINGP is typical of large midwestern rivers and the river is considered to the eutrophic (NUS 1976). Major factors affecting the river ecology are the proximity of the Twin Cities (Minneapolis and St. Paul), the lock and dam system, the wing-dam system, barge traffic, and the numerous side channels and associated lakes of the Mississippi River (NUS 1976). The river in the PINGP area has a dual character; lotic in the main channel and lentic in the associated side channels and lakes (Sturgeon and North Lake). The planktonic communities in the PINGP area are well developed due to the impoundments and the numerous slackwater areas associated with the river channel. The flushing effect of the river is somewhat compensated by recruitment from associated lentic waters (NUS 1976).

The food web structure of the Mississippi River near PINGP is. influenced by the interaction of both the lotic and lentic systems. 


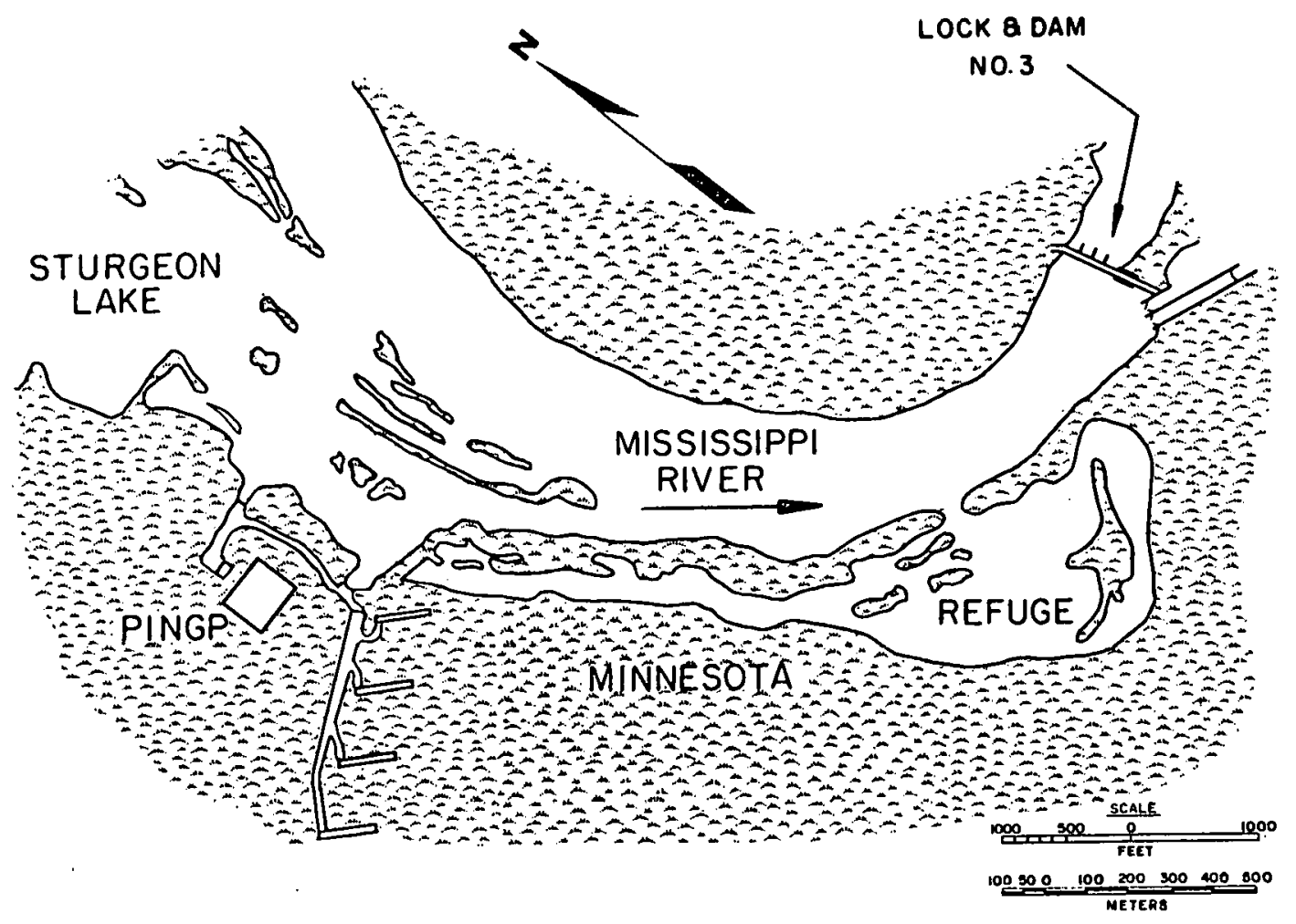

Figure 1. Location of the Prairie Island Nuclear Generating Plant on the Mississippi River $65 \mathrm{~km}$ southeast of Minneapolis, Minnesota. 
The benthic macroinvertebrate community depends primarily on suspended detritus and plankton, and this community serves as an important link in the fish food chain. The fish community near PINGP is relatively diverse, consisting of game fish (sauger, walleye, white bass, northern pike, and channel catfish), large rough fish (carp, carpsuckers, redhorse), panfish (rock bass and bluegill), minnows and darters, and others such as gizzard shad, bullheads, and freshwater drum. Most fish in the vicinity of the plant prefer shallow backwaters such as Sturgeon Lake for spawning and nursery areas. A few species such as sauger, walleye, and the suckers prefer swift flowing water for spawning while drum typically spawn in the main river channel.

The Prairie Island Nuclear Generating Plant consists of two pressurized-water nuclear steam supply and turbine-generator systems. Each system is rated at 507 MWe net in the summer (May-October) and 523 MWe net in the winter (November-April). The design waste heat load for each unit is 1150 Mwe. About $20.0 \mathrm{~m}^{3} / \mathrm{sec}(705 \mathrm{cfs})$ of water is used to remove the waste heat from each system resulting in a temperature increase across the condenser of $14.8^{\circ} \mathrm{C}(24.8 \mathrm{~F})$ at full load conditions.

Makeup water for PINGP is drawn from the Mississippi River through a skimmer wall located at the entrance of the intake canal (Fig. 1). This water, plus the water being recirculated through the recycle canal, is drawn into the intake structure and pumped into the plant. The amount of water diverted from the river into the plant depends on the plant load factor and the meteorological conditions and varies from about $5.0 \mathrm{~m}^{3} / \mathrm{sec}(175 \mathrm{cfs})$ to $39.9 \mathrm{~m}^{3} / \mathrm{sec}(1410 \mathrm{cfs})$ (Adams et al. 
1979). Water velocities in front of the intake structure bar rack range from 0.2 to $0.3 \mathrm{~m} / \mathrm{sec}(0.7$ to $1.0 \mathrm{ft} / \mathrm{sec}$ ) (Adams et al. 1979).

The main source of makeup water for the plant appears to be Sturgeon Lake instead of the main river channel. This is of ecological significance because Sturgeon Lake is not only more biologically productive than the main river, but apparently serves as a spawning and nursery area for many species of important fish (Adams et al. 1979). Baker (1975) frequently observed a continuous phytoplankton bloom extending from Sturgeon Lake to the intake canal, indicating channeling of the blue-green rich phytoplankton lake surface water into the canal. Furthermore, he observed that the productivity rates of phyto-plankton at the skimmer wall and in Sturgeon Lake were about the same, but that in the main channel productivity was considerably less. From this observation, Baker (1975) concluded that the source of plant makeup water is largely, if not entirely, from Sturgeon Lake. Szluha (1974) performed some dye studies that also indicated that the source of the plant makeup water is Sturgeon Lake. A $183 \mathrm{~m}$ wide and $3.1 \mathrm{~m}$ deep intake channel that was dredged out from the plant intake area to the main river channel has been ineffective in providing river water as the main source of makeup water (Adams et al. 1979).

\section{OPERATIONAL IMPACTS OF THE PRESENT INTAKE SYSTEM}

\section{ENTRAINMENT ISSUES}

Impacts resulting from power plant operation include entrainment and impingement. Entrainment occurs when organisms too small to be impinged on intake screens are passed through the cooling system. When 
large organisms such as fish cannot escape the intake water velocities of power plants, they become impinged upon the intake screens and ultimately die from suffocation and exhaustion (Clark and Brownell 1973).

Most of the emphasis in this section will be given to entrainment related impacts including: (1) estimating the number of adult fish that would have been produced had the eggs and/or larve not been entrained and (2) calculation of through-plant plankton survival.

\section{ENTRAINMENT IMPACTS ON ADULT FISH}

A simple technique is described by Horst (1975) for estimating the number of adult fish that would have been produced had the eggs and/or larvae not been entrained. This methodology, which is also described in the 316(b) demonstration (NUS 1976), should only be applied when it is not possible to use more sophisticated methods because of the lack of available life-history data.

Various assumptions and conventions associated with this technique can lead to a serious underestimate of the potential loss of adults. This loss to the adult population is assumed to be equal to the number of eggs and/or larvae entrained times the survival from the egg or larval stage to the age when the particular fish species reaches sexual maturity. It is assumed that the population is in equilibrium and that an average adult female will reproduce just enough female eggs to replace herself (a sex ratio of one-to-one is often assumed as it is at Prairie Island). This technique does not include any compensatory mechanisms which might partially offset losses over the short term or the long term (several generations) nor depensatory mechanisms which 
could exacerbate the loss. However, this technique also implicitly assumes that a reduction in adults of one generation does not reduce the number of adults in future generations. Such a feedback mechanism in the real population in the absence of compensation would cause the impact due to a power plant to become more severe with time. Thus, little insight is provided by this methodology into long-term effects on the fish population, and it should only be used to provide an estimate within an order of magnitude of the potential severity of an impact by a power plant (Goodyear 1978).

In this section, we will discuss several sources of bias which are present in the methodology used in the $316(b)$ demonstration (NUS 1976), and we will present refined estimates of the 1975 loss expressed as "equivalent adults" for five of the principal fish species (gizzard shad, carp, sauger, white bass, and freshwater drum) occurring near PINGP. Topics considered include: estimation of daily concentration, gear avoidance, effect of indeterminate age of entrained larvae, partially identified or unidentified eggs and/or larvae, and the estimation of expected lifetime fecundity.

\section{Estimation of daily concentration}

Pyne (1976) has shown that the maximum likelihood estimator of the average density, $D$, for $n$ separate samples from Poisson-distributed organisms, collected with varying volumes, is

$$
\bar{D}^{\star}=\sum_{i=1}^{n} N_{i} \sum_{i=1}^{n} V_{j},
$$


where $N_{i}$ is the number of ichthyoplankton found in $v_{i} m^{3}$ of water strained in the $i^{\text {th }}$ sample. Apparently, the daily concentration of the ichthyoplankton life stage was calculated in the $316(b)$ demonstration (NUS 1976) by

$$
\bar{D}^{\prime}=\frac{1}{n} \sum_{i=1}^{n} D_{i},
$$

Where $D_{i}$ a $N_{i} / V_{i}$ is the concentration ubserved in each sample during a day of sampling. In general $\bar{D}^{\star} \neq \bar{D}^{\prime}$, although the inequality can go either way. Both estimators under normality assumptions are biased (Raj 1968, problem 35); however, the Dias for $D^{\prime}$ is $n$ times the bias for $\bar{D}^{\star}$. Furthermore, if one assumes that the sampling error for the volume is very small with respect to the sampling error for the counts and can be ignored, then both estimators are unbiased. However, in this case, the variance of $\bar{D}^{\star}$ is still less than the variance of $D^{\prime}$, and thus is the preferred estimator.

The annual entrainment estimate (E) for each entrainable life stage of a species is calculated from the daily mean density during the $j^{\text {th }}$ sampling period $\left(\bar{D}_{j}^{\star}\right)$ by

$$
E=\sum_{j=1}^{k} \bar{D}^{\star} \cdot \eta^{*},
$$

where

$$
Q_{j}^{\star}=86400 \cdot Q_{j} \cdot A_{j} \cdot,
$$


86400 is the number of seconds in a day, $Q_{j}$ is the average flow rate $\left(\mathrm{m}^{3} / \mathrm{sec}\right)$ at the bar rack sampling station during the $j^{\text {th }}$ sampling periods, $A_{j}$ is the number of days during the $j^{\text {th }}$ sampling period over which the average daily concentration and flow rate are applicable, and $k$ is the number of sampling periods. The sampling schedule at the bar rack station in 1975 for which sampling volumes were available is given in Table 1 for day, night, and combined samples. Table 2 contains estimates of daily and total larvae entrainment for five important fish species using the estimator given by Eq. (1) and Eq. (3). Notice that $D_{j}^{*}$ for these five species is less than the total larvae entrained from $\bar{D}_{j}$ (Table 6.4-1, NUS 1976). Thus, correcting this error leads to a slight lessening of the projected impact of the power plant on the adult fish populations. For freshwater drum eggs, there is a decrease in the entrainment estimate from $7,484,000$ (Table $6.4-1$, NUS 1976) to $6,974,000$, or about a $7 \%$ decrease in the projected number of "equivalent drum adults" lost due to the entrainment of drum eggs. No eggs were collected in the entrainment samples in 1975 for the remaining four important fish species (gizzard shad, carp, sauger, and white bass).

Gear avoidance

The problem of gear avoidance by larvae and juveniles, and the resultant underestimation of their abundance, has been pointed out in the literature (Bjorke et al. 1974, Schnack 1974, Murphy and Clutter 1972, Kjelson 1977, Kjelson and Colby 1977, McGroddy and Wyman 1977). The use of only night samples instead of day and night samples will 
Table 1. Number of samples and sampling volumes at the bar rack station in 1975 by day and night for each sampling date at Prairie Island Nuc lear Generating Plant

\begin{tabular}{|c|c|c|c|c|c|c|c|}
\hline \multirow[b]{2}{*}{ Date } & \multicolumn{2}{|c|}{ Day } & \multicolumn{2}{|c|}{ Night } & \multicolumn{3}{|c|}{ Tota 1} \\
\hline & $\begin{array}{l}\text { No. } \\
(n)\end{array}$ & $\begin{array}{l}V_{0} l_{j}^{a} \\
\left(V_{j}\right)^{2}\end{array}$ & $\begin{array}{l}\text { No. } \\
(n)\end{array}$ & $\begin{array}{l}v_{0} l_{j}^{a} \\
\left(v_{i}\right)^{2}\end{array}$ & $\begin{array}{l}\text { No. } \\
\text { (n) }\end{array}$ & & $\begin{array}{l}\mathrm{Vol}_{0}^{\mathrm{a}} \\
\left(\mathrm{V}_{j}\right)^{-}\end{array}$ \\
\hline $\begin{array}{l}5 / 15 \\
5 / 21 \\
5 / 29 \\
6 / 5 \\
6 / 12 \\
6 / 18 \\
6 / 26 \\
7 / 2 \\
7 / 10 \\
7 / 17 \\
7 / 24 \\
7 / 31 \\
8 / 7 \\
8 / 14 \\
8 / 21 \\
9 / 4\end{array}$ & $\begin{array}{r}12 \\
12 \\
12 \\
12 \\
12 \\
12 \\
12 \\
3 \\
8 \\
-9 \\
7 \\
9 \\
9 \\
9 \\
9 \\
9\end{array}$ & $\begin{array}{r}2922.7 \\
4526.7 \\
3787.5 \\
1162.7 \\
1028.6 \\
2754.2 \\
1196.3 \\
185.8 \\
3920.3 \\
1247.0 \\
3100.6 \\
3123.8 \\
3910.2 \\
987.2 \\
159.3 .2 \\
725.2\end{array}$ & $\begin{array}{r}12 \\
12 \\
12 \\
12 \\
12 \\
12 \\
12 \\
1 \\
9 \\
9 \\
9 \\
9 \\
9 \\
6 \\
9 \\
9\end{array}$ & $\begin{array}{r}3700.4 \\
3747.4 \\
3122.6 \\
1085.0 \\
911.7 \\
1648.1 \\
1252.9 \\
153.1 \\
9808.2 \\
-1123.0 \\
4099.4 \\
3508.3 \\
2810.0 \\
770.3 \\
1887.8 \\
894.0\end{array}$ & $\begin{array}{l}24 \\
24 \\
24 \\
24 \\
24 \\
24 \\
24 \\
7 \\
18 \\
18 \\
16 \\
18 \\
18 \\
15 \\
18 \\
18\end{array}$ & - & $\begin{array}{l}6623.1 \\
8274.1 \\
6910.1 \\
2247.7 \\
1940.3 \\
4407.3 \\
2449.2 \\
319.2 \\
7310.8 \\
8370.0- \\
7200.0 \\
6632.1 \\
6720.2 \\
1757.5 \\
3481.0 \\
1619.2\end{array}$ \\
\hline Total & 157 & $38,882.0$ & 157 & $37,309.5$ & 314 & & $76,191.5$ \\
\hline
\end{tabular}

a Sample volumes are in cubic meters $\left(\mathrm{m}^{3}\right)$.

Table 2. Estimates of daily larval concentrations $\left(\# / \mathrm{m}^{3}\right)$ at the bar rack station in 1975 based on day and night samples and the total

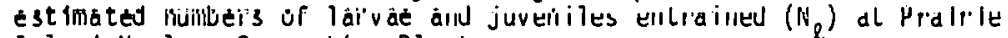
Is ? and Nur ? qar Gonerating Plant

\begin{tabular}{|c|c|c|c|c|c|c|}
\hline \multirow[b]{2}{*}{ Date } & \multicolumn{5}{|c|}{ Species } & \multirow[b]{2}{*}{ All speçięs } \\
\hline & $\begin{array}{l}\text { Gizzard } \\
\text { shad }\end{array}$ & Carp & Sauger & $\begin{array}{l}\text { White } \\
\text { bass }\end{array}$ & $\begin{array}{c}\text { Freshwater } \\
\text { drụm }\end{array}$ & \\
\hline $\begin{array}{l}5 / 15 \\
5 / 21 \\
5 / 79 \\
6 / 5 \\
6 / 12 \\
6 / 18 \\
6 / 26 \\
7 / 2 \\
7 / 10 \\
7 / 17 \\
7 / 24 \\
7 / 31 \\
8 / 7 \\
8 / 14 \\
8 / 21 \\
9 / 4\end{array}$ & $\begin{array}{l}n \\
0.00816 \\
n .09 .349 \\
0.01201 \\
0.02577 \\
0.01181 \\
0.36869 \\
0.02864 \\
0.01247 \\
0.00717 \\
0.00064 \\
0.00724 \\
0.00417 \\
0.00455 \\
0.00172 \\
0\end{array}$ & $\begin{array}{l}n . \text { nกhka } \\
0.01825 \\
n .0 n 391 \\
0 \\
0.00155 \\
0 \\
0.13841 \\
0.01145 \\
0.02 j 15 \\
0.00024 \\
0.00091 \\
0 \\
0.00030 \\
0 \\
0 \\
0\end{array}$ & $\begin{array}{l}n . \cap \cap 317 \\
0.06345 \\
n, n \cap 087 \\
0 \\
0 \\
0 \\
0 \\
0 \\
u \\
0 \\
0 \\
0 \\
0 \\
0 \\
0 \\
0\end{array}$ & $\begin{array}{l}n \\
0.02935 \\
0.02248 \\
0.12995 \\
0.01379 \\
0.05360 \\
0.00545 \\
0.00367 \\
0 \\
U \\
0.00024 \\
0.00014 \\
0 \\
0 \\
0 \\
0 \\
0\end{array}$ & $\begin{array}{l}0 \\
0.00012 \\
0.00637 \\
0.01513 \\
0.00515 \\
0.03498 \\
0.01143 \\
0.00286 \\
0.00055 \\
0.0 n 155 \\
0.01014 \\
0.00875 \\
0.00119 \\
0.00341 \\
0.00460 \\
0\end{array}$ & $\begin{array}{l}0.03473 \\
0.60067 \\
0.70766 \\
0.05917 \\
0.09483 \\
0.07042 \\
0.60183 \\
0.09164 \\
0.12903 \\
0.02377 \\
0.07000 \\
0.06951 \\
0.01503 \\
0.02731 \\
0.01609 \\
0.00123\end{array}$ \\
\hline
\end{tabular}

Total larvae and juveniles entrained:
$\left(N_{Q}\right)$
$8,785,314$
$3,049,684$
$1,374,407$
$4,742,391 \quad 2,140,954$
$49,890,336$ 
compensate partially for the avoidance capability of larvae and especially of juveniles. Table 3 parallels Table 2 but gives nighttime concentrations rather than day/night concentrations combined (samplings with starting times of 2000,0000 , and 0400 hours were considered night samples). Note that this method does not compensate for net extrusion of smaller larvae, which would have an effect similar to gear avoidance. Leithiser et al. (1979) demonstrated that for cooling water velocities of $40 \mathrm{~cm} / \mathrm{s}$ or less, a $1.0-\mathrm{m}$ net was only 79 to $85 \%$ as efficient as a high volume pump, based on night samples. This situation indicated that a sizable underestimate of the entrained ichthyoplankton may yet remain.

The number of freshwater drum eggs entrained was based on day and night samples combined, and reflects no correction for the extrusion of eggs through the net.

\section{Age of entrained life stages}

As originally formulated by Horst (1975) the "equivalent adults" method can lead to a considerable underestimate of the actual impact. A significant source of the bias from this methodology is the result of the functional nature of egg and larval survival with respect to age. Younger eggs or larvae have a lower survival to adul thood than do older eggs or larvae, respectively. The $316(\mathrm{~b})$ demonstration (NUS 1976) differentiates between eggs and larvae for this same reason in projecting "equivalent adults." The applicant has supplied the staff with a breakdown of the larval entrainment data at the bar rack station in 1975 on computer tape into four groups: protolarvae, mesolarvae, metalarvae, and juveniles (see NUS 1976, p. 151-152). 
Table 3. Estimates of daily larval concentrations $\left(\# / \mathrm{m}^{3}\right)$ at the bar rack station in 1975 based on night samples and the total estimated numbers of larvae and juveniles entrained $\left(N_{\ell}\right)$ at Prairie Island Nuclear Generating Plant

\begin{tabular}{|c|c|c|c|c|c|c|}
\hline \multirow[b]{2}{*}{ Date } & \multicolumn{5}{|c|}{ Species } & \multirow[b]{2}{*}{ All species } \\
\hline & $\begin{array}{l}\text { Gizzard } \\
\text { shad }\end{array}$ & $\begin{array}{l}-\cdot-\cdot- \\
\text { Carp }\end{array}$ & Sauger & $\begin{array}{l}\text { White } \\
\text { bass }\end{array}$ & $\begin{array}{l}\text { Freshwater } \\
\text { drum }\end{array}$ & \\
\hline $\begin{array}{l}5 / 15 \\
5 / 21 \\
5 / 29 \\
6 / 5 \\
6 / 12 \\
6 / 18 \\
6 / 26 \\
7 / 2 \\
7 / 10 \\
7 / 17 \\
7 / 24 \\
7 / 31 \\
8 / 7 \\
8 / 14 \\
8 / 21 \\
9 / 4\end{array}$ & $\begin{array}{l}0 \\
0.01494 \\
0.13675 \\
0.02120 \\
0.02413 \\
0.00971 \\
0.70636 \\
0.06519 \\
0.01919 \\
0.00485 \\
0.00098 \\
0.00827 \\
0.00747 \\
0.01039 \\
0.00159 \\
0\end{array}$ & $\begin{array}{l}0.00973 \\
0.02108 \\
0.00737 \\
0 \\
0 \\
0 \\
0.21231 \\
0.02608 \\
0.04200 \\
0.00049 \\
0.001 .46 \\
0 \\
0.00036 \\
0 \\
0 \\
0\end{array}$ & $\begin{array}{l}0.00243 \\
0.11368 \\
0.00096 \\
0 \\
0 \\
0 \\
0 \\
0 \\
0 \\
0 \\
0 \\
0 \\
0 \\
0 \\
0 \\
0\end{array}$ & $\begin{array}{l}0.00703 \\
0.03896 \\
0.14251 \\
0.02396 \\
0.10969 \\
0.00728 \\
0.00718 \\
0 \\
0 \\
0.00049 \\
0.00024 \\
0 \\
0 \\
0 \\
0 \\
0\end{array}$ & $\begin{array}{l}0 \\
0 \\
0.00769 \\
0.02857 \\
0.00439 \\
0.06068 \\
0.01756 \\
0.00652 \\
0.00056 \\
0.00145 \\
0.01220 \\
0.01283 \\
0.00142 \\
0.00519 \\
0.00424 \\
0\end{array}$ & $\begin{array}{l}0.03594 \\
0.82270 \\
0.72504 \\
0.10138 \\
0.14807 \\
0.08616 \\
1.07431 \\
0.16297 \\
0.15521 \\
0.02498 \\
0.08294 \\
0.08067 \\
0.02491 \\
0.05972 \\
0.02119 \\
0.00224\end{array}$ \\
\hline
\end{tabular}

Total larvae and juveniles entrained

$\left(N_{\ell}\right): \quad 14,720,662 \quad 4,760,335 \quad 2,372,188 \quad 6,228,438 \quad 3,188,409 \quad 64,952,096$ 
Since an individual juvenile is more likely to survive to adulthood than an individual metalarva, and since a single metalarva is more likely to survive to adulthood than a single mesolarva, and finally since one mesolarva is more likely to survive to adulthood than one protolarvae, then it is critical to know the age distribution of the entrained larvae (and juveniles). Even though most larvae entrained will usually be protolarvae, most of the potential loss to the adult population may result from the entrainment of fewer older larvae and juveniles (Goodyear 1978). Horst's method (Horst 1975) assumes that all larvae entrained have just hatched and have the whole larval stage ahead of them with all its potential sources of mortality. We will partially offset this serious source of bias by using the three larval stages (protolarva, mesolarva, and metalarva) and juveniles separately in order to determine an "equivalent protolarva." This "equivalent protolarva," using Horst's method (Horst 1975), will then be projected to an "equivalent adult." Only a more extensive breakdown of larvae by age will ultimately remove this source of bias, but the necessary data (such as length-frequency information by species) is unavailable. This crude breakdown will remove a majority of the bias.

For our five species, Table 4 shows a rough estimate of survival from one life stage to another, using all of the 1975 sampling data at the bar rack, skimmer wall, and recirculation canal stations for the five fish species. No correction was made in the survival estimates for different life stage durations. However, older life stages generally are longer in duration than younger life stages. This will result in overestimates of survival and hence underestimates of the potential 
Table 4. Estimated survival from the protolarval stage to the indicated stage in 1975 at Prairie Island Nuclear Generating Plant

\begin{tabular}{lccc}
\hline \multicolumn{1}{c}{ Species } & & Stage & \\
\hline Gizzard shad & Mesolarva & Metalarva & Juvenile \\
Carp & 0.201 & 0.073 & 0.031 \\
Sauger & 0.420 & 0.008 & $0.008^{\mathrm{a}}$ \\
White bass & 0.138 & $0.007^{\mathrm{b}}$ & - \\
Freshwater drum & 0.295 & 0.065 & 0.010 \\
\hline
\end{tabular}

More juveniles than metalarvae were caught, so survival from metalarva to juvenile was assumed equal to one. This assumption will reduce slightly the final predicted impact.

bTh is number is adjusted from 0.002; see equations (9) through (12) and associated text: 
power plant impact. All 1975 sampling data was used since only relative population estimates of the different life stages are needed for estimating survival. Also, increasing our data base will increase the precision of our estimate. The inverse of the survival from the protolarval stage to one of the later stages gives the multiplicative factor needed to convert that later stage to "equivalent protolarvae." Table 5 gives the estimated number of larvae entrained by life stage and the total "equivalent protolarvae." The last column is obtained from the equation:

$$
N_{p}=E_{p}+\frac{E_{m}}{S_{m}}+\frac{E_{t}}{S_{t}}+\frac{E_{j}}{S_{j}},
$$

where $N_{p}$ is the number of "equivalent protolarvae" resulting from entrained protolarvae $\left(E_{p}\right)$, entrained mesolarvae $\left(E_{m}\right)$, entrained metalarvae $\left(E_{t}\right)$, and entrained juveniles $\left(E_{j}\right)$. The survival to these three older stages from the protolarvae stage are given by $S_{m}$, $s_{t}, S_{j}$, respectively (Table 4$)$. It is particularly important to notice that the white bass protolarvae comprise only $26.6 \%$ of the total estimated white bass larvae entrained, and further that there are $73.9 \%$ more mesolarvae entrained than protolarvae and practically as many metalarvae entrained (99.8\%) as protolarvae. Thus, a total of $6,228,000$ larvae and juveniles white bass entrained is approximately equivalent to $40,080,000$ protolarvae entrained, or an increase of $644 \%$. Horst's method was derived under the assumption of entraining young larvae or protolarvae. Thus this intermediary step of converting 
Table 5. Entrainment by life stage at the bar rack station in 1975. using night samples

\begin{tabular}{|c|c|c|c|c|c|c|c|c|}
\hline \multirow[b]{2}{*}{ Species } & \multirow{2}{*}{$\begin{array}{l}\text { Proto- } \\
1 \text { arvae } \\
(\mathrm{PL})\end{array}$} & \multicolumn{2}{|c|}{ Mesolarvae } & \multicolumn{2}{|c|}{ Metalarvae } & \multicolumn{2}{|c|}{ Juven iles } & \multirow{2}{*}{$\begin{array}{c}\text { "Equivalent } \\
\text { protolarva" } \\
(\text { Np })^{a} \\
\left(X 10^{-3}\right)\end{array}$} \\
\hline & & $\left(x \quad 10^{-3}\right)$ & $(\% \mathrm{PL})$ & $\left(x^{10}-3\right)$ & $(\% \mathrm{PL})$ & $\left(x 10^{-3}\right)$ & $(\% \mathrm{PL})$ & \\
\hline $\begin{array}{c}\text { Gizz ard } \\
\text { shad }\end{array}$ & 12,449 & 1,933 & $(15.5)$ & 271 & $(2.2)$ & 67 & $(0.5)$ & 27,940 \\
\hline Carp & 3,787 & 940 & $(24.8)$ & .20 & $(0.5)$ & 14 & $(0.4)$ & 10,275 \\
\hline 3auyeı & 1,900 & 300 & $(19.4)$ & * & ( ) & & $(-)$ & 1,783 \\
\hline $\begin{array}{l}\text { White } \\
\text { hass }\end{array}$ & 1,658 & 2.884 & $(173.9)$ & 1,654 & $(99.8)$ & 32 & $(1.9)$ & 40,080 \\
\hline $\begin{array}{l}\text { Freshwater } \\
\text { drum. }\end{array}$ & 2,141 & 973 & $(45.4)$ & 54 & $(2.5)$ & 20 & $(0.9)$ & 6,743 \\
\hline
\end{tabular}

asee Eq. (4) and associated text. 
older larvae and juveniles to protolarvae is necessary if Horst's method is still to be used, but with these corrections.

\section{Identification problems}

Since some of the partially identified (to family or genus level), unidentified, or unidentifiable eggs or larvae might be one of the five fish species under study, a means of distributing these eggs and larvae among all completely identified species should be considered. Consider the minnow family, which includes the carp, and the 346 larvae identified only to the family level. Since 2003 carp larvae were captured compared to 4530 larvae belonging to four other identified species within the minnow family, then $30.7 \%\left(100 \times \frac{2003}{6533}\right)$ or 106 of the 346 larvae identified as minnows should be added to the carp larval entrainment. The column headed "Inflation Factor" in Table 6, represents the proportional increase to the five fish species when all partially identified and unidentified larvae have been proportionately distributed. Out of a total of 2118 eggs caught in 1975 at the bar rack station, 1951 were freshwater drum, 1 was a mooneye, and 166 were unidentified. Thus, $99.95 \%$ of 166 (rounds to 166) unidentified eggs were added to the 1951 freshwater drum eggs. This results in an inflation factor for entrained freshwater drum eggs of $1.085\left(\rho \frac{2117}{1951}\right)$. Since $6,974,000$ freshwater drum eggs were estimated to be entrained during the sampling period based on identified drum eggs, then this estimate should be increased to $7,567,000$ to account for the unidentified eggs. 
Table 6. Adjustment for identification problem in 1975 at the bar rack station at Prairic Island Nuclear Gencrating Plant

\begin{tabular}{|c|c|c|c|}
\hline Species & $\begin{array}{l}\qquad(A) \\
\text { "Equivalent } \\
\text { protolarva" } \\
(x(N)) \\
(x(10-3) b\end{array}$ & $\begin{array}{l}\text { Inflation } \\
\text { factor }\end{array}$ & $\begin{array}{l}\qquad(\mathrm{C})^{a} \\
\text { Total "equivalent } \\
\text { protolarva" (Np) } \\
\left(\times 10^{-3}\right)\end{array}$ \\
\hline Gizzard shad & 27,940 & 1.010 & 28,219 \\
\hline Carp & 10,275 & 1.083 & 11,128 \\
\hline Sauger & 4,783 & 1.221 & 5,840 \\
\hline White bass & 40,080 & 1.006 & 40,320 \\
\hline Freshwater drum & 6,743 & 1.011 & 6,817 \\
\hline
\end{tabular}

acalculated as $(A) \times(B)$.

brom Table 5. 
Fecundity and resultant projections

The final source of bias to be discussed in this section on Horst's "equivalent adults" method concerns the fecundity term. Two equations in the $316(\mathrm{~b})$ demonstration (p. 243, NUS 1976) are presented for eggs,

$$
N_{a}=S N_{e}=\frac{2}{F} N_{e} \text {, }
$$

and for larvae,

$$
N_{a}=S_{\ell} N_{l}=\frac{2}{S_{e} F} N_{\ell},
$$

where $N_{a}=$ the number of "equivalent adults" lost due to the entrainment of $\mathrm{N}_{e}$ eggs and $\mathrm{N}_{\ell}$ larvae (and juveniles) by the power plant; $S, S_{e}$ and $S_{\ell}$ are the survival from the egg to adult stage, egg to larvae stage, and larvae to adult stage, respectively; the number 2 implies a sex ratio of one-to-one, and $F$ represents a measure of female fecundity. Horst defines $F$ as "the fecundity of a breeding pair during their life." However, without correcting for adult mortality, simply summing up the female fecundity over the mature age classes will significantly overestimate the lifetime female fecundity. In the $316(\mathrm{~b})$ demonstration, this very method for obtaining what is called "total life time fecundity of a female" is employed. Overestimating $F$ will lead to an underestimate of $S$ and hence an underestimate of $S_{l}$ and the number of "equivalent adults" lost due to power plant entrainment. Dahlberg and Owen (1977), in a response to the Nuclear Regulatory Commission (NRC), note that the "egg production in the average lifetime of 
fish, rather than maximum lifetime," would be preferable. They proposed to estimate $F$ by calculating an average annual female fecundity (see walleye example on p. 9 of Dahlberg and Owen 1977) and to multiply this by the mean generation time. In order to present a "conservative" case, they substitute the age of maximum egg contribution for mean generation time. They suggest that this will underestimate $F$, and hence overestimate $S, S_{\ell}$ and $\mathrm{N}_{\mathrm{a}}$. In their example, they have averaged two immature age classes in calculating the mean lifetime fecundity. We propose instead that, in calculating the survival from the egg to adult stage, the expected lifetime egg production of a female just entering the first mature age class $\left(F_{e}\right)$ be used because it is this female that must be replaced to maintain a stable mature population. Considering the walleye example of Dahlberg and Owen (1977) and assuming, as they did, an adult annual survival of 0.5 , then

\begin{tabular}{|c|c|c|c|c|c|}
\hline $\begin{array}{c}\text { A } \\
\text { Age }\end{array}$ & & & $\begin{array}{l}\text { B̀ } \\
\text { rviving } \\
\text { ortion }\end{array}$ & $\begin{array}{l}\text { c } \\
\text { Eggs per } \\
\text { female }\end{array}$ & $\begin{array}{c}D \\
\text { Weighted eggs } \\
\text { per female }(B \times C)\end{array}$ \\
\hline $\begin{array}{r}3 \\
4 \\
5 \\
6 \\
7 \\
8 \\
9 \\
10\end{array}$ & $\begin{array}{l}1.0 \\
0.5 \\
0.25 \\
0.125 \\
0.062 \\
0.031 \\
0.015 \\
0.007\end{array}$ & $\begin{array}{l}77,0 \\
119,5 \\
180,5 \\
5 \\
25 \\
25 \\
2525 \\
78125\end{array}$ & $\begin{array}{ll}00 & 7 \\
00 & 5 \\
00 & 4 ! \\
258,00 \\
303,00 \\
333,00 \\
502,00 \\
484,00\end{array}$ & $\begin{array}{l}000 \\
750 \\
125 \\
32,250 \\
18,937 \\
10,406 \\
7,844 \\
3,781 . \\
F_{e}=255,093\end{array}$ & . \\
\hline
\end{tabular}

assuming a sex ratio of one-to-one, the survival from egg to adult stage, $S$, is

$$
S=\frac{2}{F_{e}}=\frac{2}{255,093}=0.00000784
$$


In this case the staff's estimate of $S$ is lower than that obtained by Dahlberg and Owen's method $(S=0.0000206)$, and will thus yield lower estimates of "equivalent adults" lost. The staff's methodology can be shown to be mathematically equivalent to that of Vaughan and Saila (1976) such that

$$
s=s_{0}\left(s_{1}\right)\left(s_{2}\right) \ldots\left(s_{a-1}\right),
$$

where $S_{i}$ is the annual survival rate for age class $i$, and $a$ is the first age class having sexually mature females. It should be noted at this time that for the early mature age classes not all females will be sexually mature. Hence, if one assumes that all females in the first few mature age classes are sexually mature, as has been done by both us and the applicant, then an overestimate of the expected lifetime fecundity of a female will result, which, of course, will underestimate the loss in "equivalent adults" due to power-plant entrainment. The staff and applicant have also assumed $100 \%$ efficiency in egg fertilization. If this efficiency is less than $100 \%$, then the loss in "equivalent adults" will be underestimated. Table 7 was calculated from Eq. (7) and from Vaughan and Saila (1976),

$$
s_{0}=\frac{1}{m_{1}+\sum_{i=1}^{r-j} m_{i+1}\left(_{j=1}^{i} p_{j}\right)} \text {, }
$$

where $m_{i}(i=1, \ldots, r)$ is the age-specific fecundity per individual, $S_{j}$ is the probability of surviving age class $j$, and $r$ is the oldest age class considered. A range of adult survivals $\left(S_{j}\right)$ are 
Table 7. Estimated survival to adulthood, $S$, based on age-specific fecundities for five fish species as a function of adult survivability, calculated using Eqs. (7) and (8)

\begin{tabular}{cccccc}
\hline $\begin{array}{c}\text { Annual } \\
\text { adult } \\
\text { survival }\end{array}$ & $\begin{array}{c}\text { Gizzard } \\
\text { shada }\end{array}$ & Carpb & Saugera & $\begin{array}{c}\text { White } \\
\text { bass }\end{array}$ & $\begin{array}{c}\text { Freshwater } \\
\text { druma }\end{array}$ \\
\hline 0.1 & 0.0000197 & 0.0000304 & 0.000131 & 0.0000117 & 0.0000231 \\
0.2 & 0.0000132 & 0.0000211 & 0.000111 & 0.0000084 & 0.0000179 \\
0.3 & 0.0000093 & 0.0000144 & 0.000092 & 0.0000060 & 0.0000132 \\
0.4 & 0.0000068 & 0.0000095 & 0.000074 & 0.0000042 & 0.0000093 \\
0.5 & 0.0000050 & $0.000 n 060$ & 0.000057 & 0.0000030 & 0.0000063 \\
0.6 & 0.0000038 & 0.0000036 & 0.000044 & 0.0000021 & 0.0000041 \\
0.7 & $0.00 n n n 29$ & 0.0000020 & 0.000032 & 0.0000014 & 0.0000027 \\
0.8 & 0.0000022 & 0.0000010 & 0.000024 & 0.0000010 & 0.0000018 \\
0.9 & 0.0000017 & 0.0000005 & 0.000017 & 0.0000007 & 0.0000010 \\
\hline
\end{tabular}

aFecundity data obtained from NUS Corporation in a letter dated May 26, 1978. bSwee, U. B., and H. R. McCrimmon. 1966. Reproductive biology of the carp, Cyprinus carpio L., in Lake St. Lawrence, Ontario. Trans. Am. Fish. Soc. $95(4): 372-380$. 
used in this table, but only $S_{j}=0.5$ for all age classes $j$ will be discussed. Note in Table 7 that $S$, the survival from spawning to the first age-class having sexually mature females, decreases with increasing adult survivability. Thus, high adult mortality will increase $S$, and also increase the predicted impact.

With this new set of estimates of spawning-to-adult-stage survival (assuming an adult survival of 0.5), a table similar to Table 6.4-1 in the $316(b)$ demonstration (NUS 1976) can be generated (Table 8). The egg stage survivals are from Dahlberg and Owen (1977). Data on fecundity for gizzard shad, sauger, white bass, and freshwater drum were provided by NUS Corporation, in a letter dated May 26, 1978, while the carp fecundity data were found in Swee and Mccrimmon (1966).

Since Eq. (7) fixes survival. from spawning to the first adult age class $(S)$, egg stage survival $\left(S_{e}\right)$ and larva to adult survival $\left(S_{\ell}\right)$ are inversely proportional $\left(S=S_{e} \cdot S_{\ell}\right)$. Hence; the greater the survival from for the egg. stage, the lower the impact (i.e., the smaller $S_{\ell}$ will be).

An inconsistency was noted in comparing Table 4 with Table 8 for sauger with respect to larval survival. The survival probability from larva to adult, $S_{\ell}$, based on the lower egg survival estimate, $S_{e}=0.005$, from Dahlberg and Owen (1977), was determined from the following equation:

$$
S_{l}=S / S_{e},
$$

where $S=0.0000574$ (see Table 8), $S_{e}=0.005$, and $S_{\ell}=0.0115$. However, $S_{l}$ exceeds the survival from protolarva to metalarva, 
Table 8. Calculation of "equivalent adults" lost due to the entrainment of fish eggs, larvae and juveniles in 1975 at Prairie Island Nuclear Generating Plant after correcting for several sources of bias and assuming an adult annual survival rate of 0.5

\begin{tabular}{|c|c|c|c|c|c|c|}
\hline Species & $\begin{array}{l}\text { Total } \\
\text { "equivalent } \\
\text { protol larvae" } \\
\left(\mathbb{N}_{\ell}\right)^{a}\end{array}$ & $\begin{array}{l}\text { Initial } \\
\text { age class } \\
\text { of maturit } y^{b}\end{array}$ & $\begin{array}{c}\text { Egg } \\
\text { stage } \\
\text { survival } \\
\left(S_{e}\right)^{c}\end{array}$ & $\begin{array}{l}\text { Spawning } \\
\text { to aduit } \\
\text { survival } \\
(S)\end{array}$ & $\begin{array}{c}\text { Larva to } \\
\text { adult } \\
\text { survival } \\
\left(S_{Q}\right)^{e}\end{array}$ & $\begin{array}{c}\text { "Equivalent } \\
\text { adults" } \\
\left(\mathrm{Na}_{\mathrm{a}}\right)^{f}\end{array}$ \\
\hline $\begin{array}{l}\text { Gizzard } \\
\text { shad }\end{array}$ & $28,219,000$ & 1 & 0.005 & 0.0000050 & 0.0010 & 28,460 \\
\hline Carp & $11,128,000$ & 4 & $0.005-0.94$ & 0.0000060 & $0.0000064-0.0012$ & $72-13,448$ \\
\hline Sauger & $5,840,000$ & 4 & $0.017-0.259$ & 0.0000574 & $0.000230-0.0034$ & $1,341-19,719$ \\
\hline $\begin{array}{l}\text { White } \\
\text { bass }\end{array}$ & $40,320,000$ & 2 & $0.003-0.10$ & 0.0000030 & $0.00003-0.00010$ & $1,191-39,691$ \\
\hline $\begin{array}{l}\text { Freshwater } \\
\text { larvae }+ \\
\text { juveniles }\end{array}$ & $6 ; 817,000$ & 5 & $0.06-0.36$ & 0.0000063 & $0.0000175-0.0001$ & $119-712$ \\
\hline Eggsh & $7,567,000$ & 5 & - & 0.0000063 & - & 47 \\
\hline
\end{tabular}

Trom Tablo 6.

bLetter of May 26, 1978, from V. R. Kranz to S. M. Adams.

Cnahihero, M. D.. and B. B. Owen. 1977. Response to WRC Questions of September 26, 1977, Concerning Requested Changes to the Technical Specifications, Appendix B, Kelating to Closed-lycle Uperailuns at Pralr ie Islanid Nuc lear Generating 81 ant. Docket Nos. 50-282, 50-306. Octuber 1977.

dfrom Table 7.

esee Eq. (9).

fSee Eqs. (5) and (6).

This number is adjusted from 0.005; see equations (9) through (12) and associated text.

hTh is row contains the number of freshwater drum eggs entrained and computes egg to adult survival and the "equivalent aduits" lost to the population due to entrainment. 
$S_{t}$, a period of shorter duration within the larva to adult period; i.e., $S_{t}=0.002$, given in a footnote to Table 4 . This conflict arose from calculating two independent estimates of larval survival, one of which $\left(S_{t}\right)$ was a subset of the other $\left(S_{l}\right)$. Obviously, $S_{t}$, the survival from protolarva to metalarva, must be greater than $S_{l}$, the survival from protolarva to adulthood. Since these estimates were obtained independently, each with considerable uncertainty, an inconsistency was possible. This, in fact, occurred for sauger. In this case the lower end of the egg survival. $\left(S_{e}\right)$ range, as proposed by the applicant, together with the fecundity analysis, implied a higher larval survival than did the concentration data used in calculating survival within the larval stage. Therefore, the lower bound of $S_{e}$ needed to be increased, $S_{t}$ needed to be increased, or both. Because estimates had a high degree of uncertainty, it was not obvious which should be adjusted to rectify this inconsistency, so both estimates were comparably adjusted according to the procedure described in the next paragraph.

Since the converse of Eq. (9) is given by

$$
S_{e}=S / S_{l}
$$

and if we assume $50 \%$ survival from the metalarva stage to adulthood ( $S=0.5 S_{t}$; probably an overestimate of survival for this period), then

$$
S_{e}=2 S / S_{t}
$$


Thus, using the initial value for $s_{t}$ of 0.002 in Table 4, a revised estimate of the lower bound for $S_{e}$ would be 0.0574 . To adjust both $S_{t}$ and the lower bound of $S_{e}$, the geometric mean of 0.0574 and 0.005 was calculated to be 0.017 , and this value was then used in Table 8 as the new lower bound of $S_{e}$. Furthermore, again assuming that $S_{\ell}=0.05 S_{t}$ and using the compromise estimate of the lower bound for $S_{e}$, then

$$
S_{t}=2 S / S_{\theta}=0.007,
$$

which is the value for $S_{t}$ (survival from protolarva to metalarva) appearing in Table 4.

In order to compare our final results with those of the applicant [316(b) demonstration, NUS 1976], geometric means of the ranges in estimated losses (Table 8) were calculated, and are presented in Table 9 with the applicant's. Only for sauger and freshwater drum was the staff's intermediate estimate of "equivalent adult" loss smaller than that of the applicant (by a factor of 1.1 and 3.5 , respectively). The carp intermediate estimate is still fairly small (984), while the impact on the abundant gizzard shad, in spite of the large estimated loss $(28,460)$, is probably not of concern.

Population estimates of white bass and sauger (both sport fishes) in the 12-mile Prairie Island Nuclear Generating Plant (PINGP) study area are given in Table 4.3-14 of the 316(b) demonstration (NUS 1976). Both the Petersen and the Schnabel estimates are given for the two species, and are estimates of the population numbers within the "angling size range" (NUS 1976). Arithmetic averages of these two 
Table 9. A partial comparison of the predicted loss in "equivalent adults" between Table 6.4-1 of the 316 (b) demonstration (NUS 1976) and Table 8 for 1975 at Prairie Island Nuclear Generating Plant

\begin{tabular}{lrrr}
\hline \multicolumn{1}{c}{ Species } & $\begin{array}{c}316(\mathrm{~b}) \\
\text { estimates }\end{array}$ & $\begin{array}{c}\text { ORNL } \\
\text { estimates }\end{array}$ & $\begin{array}{r}\text { Ratio of } \\
\text { estimates }\end{array}$ \\
\hline Gizzard shad & 3,111 & 28,460 & 9.1 \\
Carp. & 195 & $984^{\mathrm{b}}$ & 5.0 \\
Sauger. & 5,643 & $5,142^{\mathrm{b}}$ & 0.9 \\
$\begin{array}{l}\text { White bass } \\
\text { Freshwater drum: } \\
\text { Larvae + juveniles }\end{array}$ & 1,022 & $6,875^{\mathrm{b}}$ & 9.4 \\
Eggs & 11 & $291^{\mathrm{b}}$ & 0.3 \\
Total drum & 1,033 & 47 & 4.3 \\
\hline
\end{tabular}

aRatio $=$ (ORNL estimates) $/(316$ (b) estimates).

bThese estimates are based on the geometric means (GM) of the ranges

given in Table 8; i.e.,

$$
G M=\sqrt{(\text { lower })(\text { upper })} .
$$


estimates for white bass $(164,623)$ and sauger $(419,297)$ will be compared with the range of "equivalent adult" losses of white bass $(1,191-39,69\}$ age class 2 fish) and sauger $(1,341-19,719$ age class 4 fish) (Table 8). Tagged fish (including white bass and sauger) were released near PINGP in 1973, 1974, and 1975. Tagged white bass and sauger were recaptured via angling, trap net, electro-fishing, gill net, saine, and trash basket (1etter dated June 8, 1978, from J. L. Geiss, Minnesota Department of Natural Resources, to S. M. Adams, Oak Ridge National Laboratory). Since the recaptures were often made a considerable distance from their release point [average distance moved in 1975 was 52.6 miles for white bass and 17.6 miles for sauger (NUS 1976)], these population estimates may be more indicative of the population size over a much wider range than the 12-mile PINGP study area. These population estimates are limited to those age classes represented within the tagged group of fish.

The ranges in estimated "equivalent adult" loss for white bass $(1,191-39,691)$ and sauger $(1,341-19,719)$ are based on age class 2 and age class 4 fish, respectively (Table 8 ). It has been suggested that immature white bass (age class 1) are of catchable size (letter dated April 12, 1979, from M. J. Lahtinen, Minnesota Pollution Control Administration, to S. Hildebrand, Oak Ridge National Laboratory), and that sauger generally enter the sport. fishery during their third year of growth (age class 2) (office memorandum dated January 29, 1979, from J. L. Geiss, Minnesota Department of Natural Resources to M. J. Lahtinen, Minnesota Pollution Control Administration). The immature white bass and sauger may be included in the population esti- 
mates given in the previous paragraph. Assuming an annual adult mortality of 0.5 for white bass and sauger, the "equivalent adult" loss for any age class can be converted to the "equivalent adult" loss for the previous age class by dividing the former "equivalent adult" loss by 0.5 . Hence, the range in loss of white bass is 2,382 to 79,382 age class 1 fish. The range in loss of sauger is 2,682 to 39,438 age class 3 fish; or 5,364 to 78,876 age class 2 fish. Since the age class 1 white bass and age class 2 sauger are not fully recruited into their respective sport fisheries, we will use a geometric mean of losses to age classes 1 and 2 for white bass $(1,684-56,131)$ and age classes 2 and 3 for sauger $(3,793-55,774)$. A direct comparison of these ranges to their respective population estimates $11-34 \%$ for white bass and 1-13\% for sauger) represent the immediate percent loss to the fishery the first year that the entrained larvae would have entered the fishery. These ranges would underestimate the percent loss to the fisheries for later years.

An alternate approach would be to compare the loss to an age class (expressed as "equivalent adults") to that proportion of the population estimate which represents that same age class. This is equivalent mathematically to spreading out the loss to the age class first entering the fishery over all age classes repesented within the fishery. In the following estimates, only half of the first fished age class (age class 1 for white bass and age class 2 for sauger) will be considered to have entered the fishery (i.e., half of the first fished age class will be represented in the population estimates). If we continue our assumption of an annual adult mortality for white bass and sauger, then 
we can represent the first and second fished age class by 1 , the third fished age class by $1 / 2$, the fourth fished age class by $1 / 4$, the fifth fished age class by $1 / 8$, and so on. A maximum of seven age classes for white bass and nine age classes for sauger are assumed lletter dated May 26, 1978, from V. R. Kranz, NUS Corporation to S. M. Adams, Oak Ridge National Laboratory). Dividing 1 by the sum of the series provides a fraction of which the population estimate of either white bass or sauger population can be reduced so as to represent the population size of the second fished age class 10.337 for age class 2 for white bass, and 0.335 for age class 3 for saugerl. A ratio of the "equivalent adult" loss as age class 2 for white bass to the reduced population estimate representing age class 2 white bass $(55,478)$ provides a range in the percent loss to the white bass fishery under equilibrium conditions (2-72\%). Similarly, based on age class 3 sauger $(70,249)$, this ratio provides a range in percent. loss to the sauger tishery under equilibrium conditions (2-28\%). If the actual losses for white bass and sauger are at the high end of their respective impact ranges, then a substantial problem may exist for these two fish species as a result of the present operation of the Prairie Island Nuclear Generating Plant. In concluding this section on "equivalent adults," we have attempted to correct for several sources of bias, including (1) estimation of concentrations, (2) gear avoidance, (3) effect of multi-aged larvae, (4) partially identified and unidentified eggs and/or larvae, and (5) estimation of expected lifetime fecundity. The method for estimating daily concentrations (which is generally preferred) leads to a decrease in estimated losses of adults due to the annual entrainment 
of eggs and/or larvae in comparison to the applicant's methodology. However, combining this method with further refinements, such as partially correcting for gear avoidance, adjusting for partially identified and unidentified eggs and/or larvae, and using the proper technique for estimating expected lifetime fecundity, leads to an increase in our impact estimates compared to those of the $316(b)$ demonstration (NUS 1976).

In general, the greatest effect (increase in impact projected) results from correcting for the indeterminate age of entrained larvae by the power plant (PINGP). However, we have only partially corrected for this bias by breaking down entrainment estimates into protolarvae, mesolarvae, metalarvae, and juveniles; some bias remains. No correction for the indeterminate age of entrained eggs was made (this oniy applies to freshwater drum). Furthermore, the technique for calculating the within-stage survival for the four "larval" stages assumes that the durations of these four stages are the same. If we assume that the older stages have longer durations than the earlier stages, as seems likely, then these estimated survivals are greater than the true survival rates, leading to an underestimate of the loss.

Two additional sources of bias may also tend to underestimate the losses as "equivalent adults." First, sorting efficiency has been assumed to be $100 \%$. If a sorter does not pick out all of the fish in a sample, then the estimated number of ichthyoplankton entrained will be low. Second, any entrainment occurring before or after the sampling period will lead to an underestimate of the number of ichthyoplankton entrained. These two biases, as well as biases due to gear avoidance, 
net extrusion, and within-stage mortality, indicate that the actual losses may be in the upper, rather than the lower, portion of the range of losses as "equivalent adults."

In particular, we believe that the true impact on white bass will be toward the upper portion of the projected impact range, and there is a reasonable possibility that a substantial impact on white bass may be occurring.

\section{ENTRAINMENT SURVIVAL OF PLANKTON}

Calculation of through-plant survival of plankton is an important consideration in determining entrainment impacts. By ignoring the potential through-plant survival, there is a tendency to overpredict potential impacts.

Zooplankton entrainment studies were conducted at the Prairie Island Nuclear Generating Plant (PINGP) and reported in the $316(b)$ demonstration (NUS 1976). The following independent analysis of through-plant mortality was conducted for the purpose of recommending meaningful sampling programs for entrainment survival of ichthyoplankton and zooplankton. These considerations are important for future monitoring in determining the effectiveness of proposed intake modifications.

An obvious and important, but sometimes neglected, result from statistical theory is that the power of a statistical test increases as the sample size increases. The power of a statistical test is equal to one minus the probability of a type-II error $(\beta)$, or one minus the probability of failing to reject the null hypothesis (in general, no 
difference or no effect) when it is in fact false. For present purposes, the power of a statistical test indicates the ability of this test to detect differences between proportions, or to detect whether the proportion of organisms killed by entrainment in a power plant is different from zero.

The 316(b) demonstration (p. 144, NUS 1976) states that "counts of organisms from the intake and discharge canals were compared using the students two-tailed t-test." Since details of the conduct of this test are not given, rather than reproducing the applicant's analysis, an independent analysis of through-plant entrainment mortality was performed.

The following test is used for differences in proportions (Fleiss 1973, Eq. 2.5):

$$
Z=\frac{\left|P_{I}-P_{D}\right|-1 / 2\left(\frac{1}{n_{I}}+\frac{1}{n_{D}}\right)}{\sqrt{\bar{P} \bar{Q}\left(\frac{1}{n_{I}}+\frac{1}{n_{D}}\right)}},
$$

where $Z$ is the standard normal deviate, which can be tested using standard normal statistical tables, $P_{I}$ and $P_{D}$ are the observed proportions alive at the intake and discharge stations, $n_{I}$ and $n_{D}$ are the corresponding total counts at the intake and discharge sampling stations, and

$$
\bar{P}=1-\bar{Q}=\frac{P_{I}+P_{D}}{2} \text {. }
$$


This test is equivalent to testing the null hypothesis $H_{0}: f_{C}=0$, where $f_{c}$ is the through-plant entrainment mortality $\left(f_{C}=1-\frac{P_{D}}{P_{I}}\right)$ (Barnthouse et al. 1977) and is equivalent under the null hypothesis $\left(H_{0}: P_{I}=\cdot P_{D}\right)$ to the test used by Ecological Analysts, Inc. $(1977 a, b)$. The alternative hypothesis $H_{A}: f_{c}>0$ is equivalent to $H_{A}: P_{I},>P_{D}$, so that a one-tailed test is indicated, which incidentally increases the power of the test. Thus, Eq. (13) is used to consider whether the data are adequate to show that there is mortality through the plant.

In any statistical test the investigator initially sets his type I error $(\alpha)$, or probability of rejecting the null hypothesis (e.g., $\left.H_{0}: f_{C}=0\right)$ when the null hypothesis is true. However, once a has been chosen, it is the sample size, $n$, and true value of $f_{c}$ that determine the power $(1-\beta)$ of the test. Tables 10-13 have been generated by the staff for four assumed values of $t_{c}(0.25,0.5$, 0.75 , and 1.0$)$ based on Fleiss (1973). These tables give the necessary sample size $\left(n=n_{I}=n_{D}\right)$ for detecting as significantly different from zero an underlying value of $f_{c}$ for two levels of $\alpha$, six power levels $(1-\beta)$, and five values of the proportion surviving at the intake $\left(P_{T}\right)$.

The variable $P_{I}$ serves as a control for the variable $P_{D}$. The variable $P_{I}$, or the fraction alive at the intake station, represents losses due to both sampling mortality and the presence of dead organisms from the river prior to sampling. The methodology used in this report assumes that the sampling mortality and number of organisms already dead from the river, are the same (jointly) for both the intake and discharge sampling stations. 
Table 10. Sample size, $n$, required to detect an underlying through-plant mortality, $f$, of 0.25 using Fle iss' testa for differences in proportions (one-tailed) for a range of powers, $1-\beta$, two levels of significance, $\alpha$, and a, range of sampling survivals at the intake, I.

\begin{tabular}{|c|c|c|c|c|c|c|}
\hline \multirow{2}{*}{$\begin{array}{l}\text { Sampling } \\
\text { survival } \\
\left(P_{I}\right)\end{array}$} & \multicolumn{6}{|c|}{ Power $=1-B$} \\
\hline & 0.990 & 0.950 & 0.900 & 0.800 & 0.700 & 0.500 \\
\hline \multicolumn{7}{|l|}{$\alpha=0.05:$} \\
\hline 0.1 & 4183 & 2921 & 2344 & 1736 & 1357 & 844 \\
\hline 0.3 & 1134 & 795 & 640 & 477 & 375 & 237 \\
\hline 0.5 & 524 & 370 & 299 & 225 & 178 & 115 \\
\hline 0.7 & 262 & 187 & 153 & 117 & 91 & 63 \\
\hline 0.9 & 117 & 86 & 71 & 56 & 47 & 33 \\
\hline \multicolumn{7}{|l|}{$a=0.01:$} \\
\hline 0.1 & 5683 & 4184 & 3482 & 2721 & 2232 & 1538 \\
\hline 0.3 & 1537 & 1135 & 946 & 742 & 611 & 424 \\
\hline 0.5 & 708 & 525 & 439 & 346. & 286 & 201 \\
\hline 0.7 & 352 & 263 & 222 & 176 & 147 & 105 \\
\hline 0.9 & 155 & 118 & 101 & 82 & 70 & 52 \\
\hline
\end{tabular}

afleiss, J. L. 1973. Statistical Methods for Rates and Proportions. John Wiley and Sons, New York. 223 pp.

Table 11. Sample size, $n$, required to detect an underlying through-plant mortality. ' $f_{c}$. of 0.5 using fle iss' testa for differences in proportions (one-tailed) for a range of powers, 1- $\beta$, two levels of significance, $\alpha$, and a range of sampling survivals at the intake, $P_{1}$

\begin{tabular}{|c|c|c|c|c|c|c|}
\hline \multirow{2}{*}{$\begin{array}{l}\text { Sampling } \\
\text { survival } \\
\left(P_{I}\right)\end{array}$} & \multicolumn{6}{|c|}{ Power $=1-B$} \\
\hline & 0.990 & 0.950 & 0.900 & 0.800 & 0.700 & 0.500 \\
\hline \multicolumn{7}{|l|}{$\alpha=0.05:$} \\
\hline 0.1 & 949 & 676 & 551 & 418 & 336 & 223 \\
\hline 0.3 & 266 & 191 & 156 & 120 & 97 & 66 \\
\hline 0.5 & 129 & 94 & 78 & 60 & 49 & 34 \\
\hline 0.7 & 70 & 52 & 44 & 35 & 29 & 21 \\
\hline 0.9 & 38 & 29 & 25 & 20 & 17 & 13 \\
\hline \multicolumn{7}{|l|}{$\alpha=0.01:$} \\
\hline 0.1 & 1274 & $\underline{900}$ & 7998 & 633 & $5 \underset{2}{2} 7$ & 376 \\
\hline 0.3 & 356 & 267 & 225 & 130 & 151 & 109 \\
\hline 0.5 & 172 & 130 & 111 & 89 & 75 & 55 \\
\hline 0.7 & 94 & 72 & 62 & 50 & 43 & 32 \\
\hline 0.9 & 50 & 39 & 31 & 29 & 25 & 20 \\
\hline
\end{tabular}

afleiss, J. L. 1973. Statistical Methods for Rates and Proportions. John Wiley and Sons, New York. $223 \mathrm{pp.}$ 
Table 12. Sample size, $n$, required to detect an underlying through-plant mortality, $f f$, of 0.75 using Fle iss' testa for differences in proportions (one-tailed) for a range of powers, 1- 8 , two levels of significance, $\alpha$, and a range of sampling survivals at the intake,

$P_{1}$

\begin{tabular}{|c|c|c|c|c|c|c|}
\hline \multirow{2}{*}{$\begin{array}{l}\text { Sampling } \\
\text { survival } \\
\left(P_{I}\right)\end{array}$} & \multicolumn{6}{|c|}{ Power $=1-\beta$} \\
\hline & 0.990 & 0.950 & 0.900 & 0.800 & 0.700 & 0.500 \\
\hline \multicolumn{7}{|l|}{$x=0.05:$} \\
\hline 0.1 & 375 & 274 & 227 & 177 & 146 & 103 \\
\hline 0.3 & 107 & 79 & 66 & 52 & 44 & 32 \\
\hline 0.5 & 54 & 40 & 34 & 27 & 23 & 17 \\
\hline 0.7 & 31 & 24 & 20 & 17 & 14 & 11 \\
\hline 0.9 & 18 & 11 & $d a$ & il & $\dot{y}$ & 8 \\
\hline$\alpha=0.01:$ & & - & $-\cdots$ & & 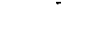 & \\
\hline 0.1 & 497 & 377 & 320 & 250 & 219 & 162 \\
\hline 0.3 & 142 & 109 & 93 & 76 & 65 & 49 \\
\hline 0.5 & 71 & 55 & 47 & 39 & 34 & 26 \\
\hline 0.7 & 40 & 32 & 28 & 24 & 21 & 10 \\
\hline 0.9 & 23 & 19 & 17 & 15 & 13 & 11 \\
\hline
\end{tabular}

afleiss, J. L. 1973. Statistical Methods for Rates and Proportions. John Wiley and Sons, New York. 223 pp.

Table 13. Sample size, $n$, required to detect an underlying through-plant mortality, $f_{C}$, of 1.0 using Fleiss' testa for differences in jiojortions (one-talled) for o range of pawcrs, 1-0 , two levels of significance. $\alpha$, and a ranqe of sampling survivals at the intake. $P_{1}$

\begin{tabular}{|c|c|c|c|c|c|c|}
\hline \multirow{2}{*}{$\begin{array}{l}\text { Samp Iing } \\
\text { survival } \\
\left(P_{I}\right)\end{array}$} & \multicolumn{6}{|c|}{ Power $=1-b$} \\
\hline & 0.990 & 0.950 & 0.900 & 0.800 & 0.700 & 0.500 \\
\hline \multicolumn{7}{|l|}{$\alpha=0.05:$} \\
\hline 0.1 & 1893 & 137 & $11 \kappa$ & 97 & 79 & 59 \\
\hline 0.3 & 52 & 40 & 34 & 28 & 24 & 19 \\
\hline 0.5 & 26 & 21 & 18 & 15 & 13 & 11 \\
\hline 0.7 & 15 & 12 & 11 & 9 & 8 & 7 \\
\hline 0.9 & 8 & 7 & 7 & 6 & 6 & 5 \\
\hline
\end{tabular}

$a=0.01:$

$\begin{array}{rrrrrrr}0.1 & 238 & 184 & 159 & 131 & 113 & 87 \\ 0.3 & 68 & 54 & 47 & 39 & 34 & 27 \\ 0.5 & 34 & 28 & 24 & 21 & 19 & 15 \\ 0.7 & 19 & 16 & 15 & 13 & 12 & 10 \\ 0.9 & 11 & 10 & 9 & 8 & 8 & 7\end{array}$

afleiss, J. L. 197,3. Statistical Methods for Rates and Proportions. John Wiley and Sons, New York. 223 pp. 
This series of four tables (Tables 10-13) indicates several important points. First, improving sampling techniques to decrease the sampling mortality at both the intake and discharge (i.e., increase $P_{I}$ ) reduces the sample size required for given levels of $\alpha$ and B. Second, increasing the sample size increases the power of the test, $i . e .$, reduces the type II error ( $\beta)$. Furthermore, increasing will either decrease the needed sample size $(n)$ for a given power, or increase the power of the test $(1-\beta)$ for a given $n$. In obtaining a low $\beta$ (type II error), the ability to detect a nonzero $f_{c}$ is, by definition, increased. This is, of course, desirable. In order to obtain a lower $\beta$, however, one must either increase the sample size (not always possible), or tolerate a large $\alpha$.

If the experiment has been completed, in the sense that no more samples can be obtained, it becomes of interest to determine the minimum underlying $f_{c}$ that can be detected, given the observed sampling survival at the intake, $P_{I}$, and the sample size at the intake and discharge, $n$. Table 14 summarizes these minimum detectable $f_{c}$ values for $\alpha=0.05$, five values of $P_{I}$, and 28 values of $n$. These values were calculated based on the following derivation using Eq. (13) and assuming $n=n_{I}=n_{D}$; i.e.,

$$
Z=\frac{P_{I}-P_{D}-1 / n}{\sqrt{2 \bar{P} \bar{Q} / n}} .
$$

Substituting Eq. (14) into Eq. (15) for $\bar{P}$ and $\bar{Q}$, one obtains

$$
Z=\frac{P_{I}-P_{D}-1 / n}{\sqrt{\frac{\left(2\left(P_{I}+P_{D}\right)\right.}{2} \frac{\left(2-P_{I}-P_{D} / n\right)}{2}}},
$$


Table 14. The lowest observed through-plant entrainment mortality, $f_{c}$, detectable as significantly greater than zero as a function of sampling survival at the intake $\left(P_{I}\right)$ and sample size $(n)$ with $\alpha=0.05$

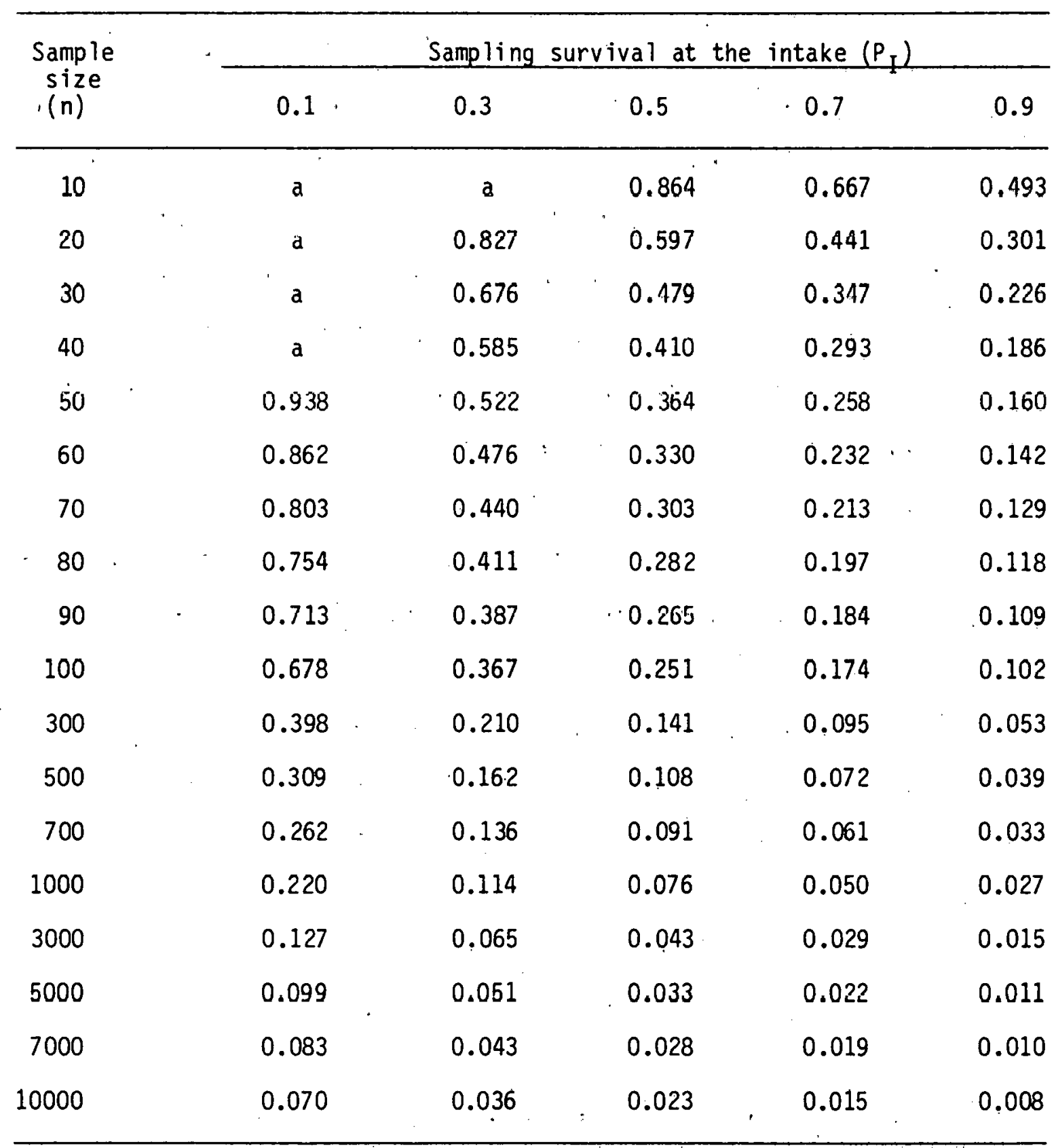

aNot significant for any value of $f_{C} \leq 1$. 
or.

$$
\frac{Z^{2}}{2 n}\left(P_{I}+P_{D}\right)\left(2-P_{I}-P_{D}\right)=\left(P_{I}-P_{D}-1 / n\right)^{2} .
$$

Rearranging terms and multiplying, we get

$$
\begin{aligned}
& Z^{2} \cdot\left(2 P_{I}+2 P_{D}-2 P_{I} P_{D}-P_{I}^{2}-P_{D}^{2}\right) \\
& =2 n\left(P_{I}^{2}+P_{D}^{2}+\frac{1}{n^{2}}-\frac{2 P_{I}}{n}+\frac{2 P_{D}}{n}-2 P_{I} P_{D}\right),
\end{aligned}
$$

and collecting terms, we obtain

$$
\begin{aligned}
& P_{D}^{2}\left(Z^{2}+2 n\right)+P_{D}\left[\left(2 z^{2}-4 n\right) P_{I}-2 Z^{2}+4\right] \\
& +P_{I}^{2}\left(Z^{2}+2 n\right)-P_{I}\left(2 Z^{2}+4\right)+2 / n=0 .
\end{aligned}
$$

Since this is a quadratic equation in $P_{D}$, then

$$
P_{D}=-\frac{b \sqrt{b^{2}-4 a c}}{2 a} \text {, }
$$

where

$$
\begin{aligned}
& a=z^{2}+2 n, \\
& b=\left(2 z^{2}-4 n\right) P_{I}-2 Z^{2}+4,
\end{aligned}
$$

and

$$
c=P_{I}^{2}\left(z^{2}+2 n\right)-P_{I}\left(2 z^{2}+4\right)+2 / n \text {. }
$$

Furthermore, since $P_{D}<P_{I}$, then

$$
P_{D}=-\frac{b-\sqrt{b^{2}-4 a c}}{2 a} .
$$


Figure 2 further illustrates the significance of Table 14. The desirable situation is to minimize the detectable $f_{c}$. Two obvious points of interest are that the minimum detectable $f_{c}$ decreases with increasing sample size, $n$, for a given sampling survival and with increasing sampling survival (estimated by $P_{I}$ ) for a given sample size. Notice the rapid decline in minimum detectable $f_{c}$ corresponding to moderate increases in sample size and sampling survival when $n$ and $P_{I}$ are initially small. This result points out that there are substantial gains in usefulness of the data when sample sizes are adequate and gear (or sampling) mortality is reasonably low. Fürther increases in either sample size or survival place one on a reasonably level "plateau," which indicates there is little to be gained by expending further effort on sampling or gear development. In general, it would be desirable to be able to detect reasonably small $f_{c}$ 's, but wasteful to be operating in a level region of the graph. In the $316(b)$ demonstration (NUS 1976), only the sample sizes for Rotifera approach this desirable state; for other taxa, there is inadequate sample size to detect any but substantial $f_{C}$ values.

If sample sizes are increased by increasing sampling duration, a decrease in sampling survival would probably result. Thus, a given sampling technique will have an optimum combination of sample size and sampling survival which will minimize the detectable $f_{c}$. Furthermore, this optimum combination will be seasonally dependent because of seasonal variations in ambient temperature which affects the size of the underlying $f_{c}$ to be estimated. Also, depending on the use for which the estimated $f_{c}$ is intended, one must decide how small a value of $f_{c}$ it is necessary to detect. 


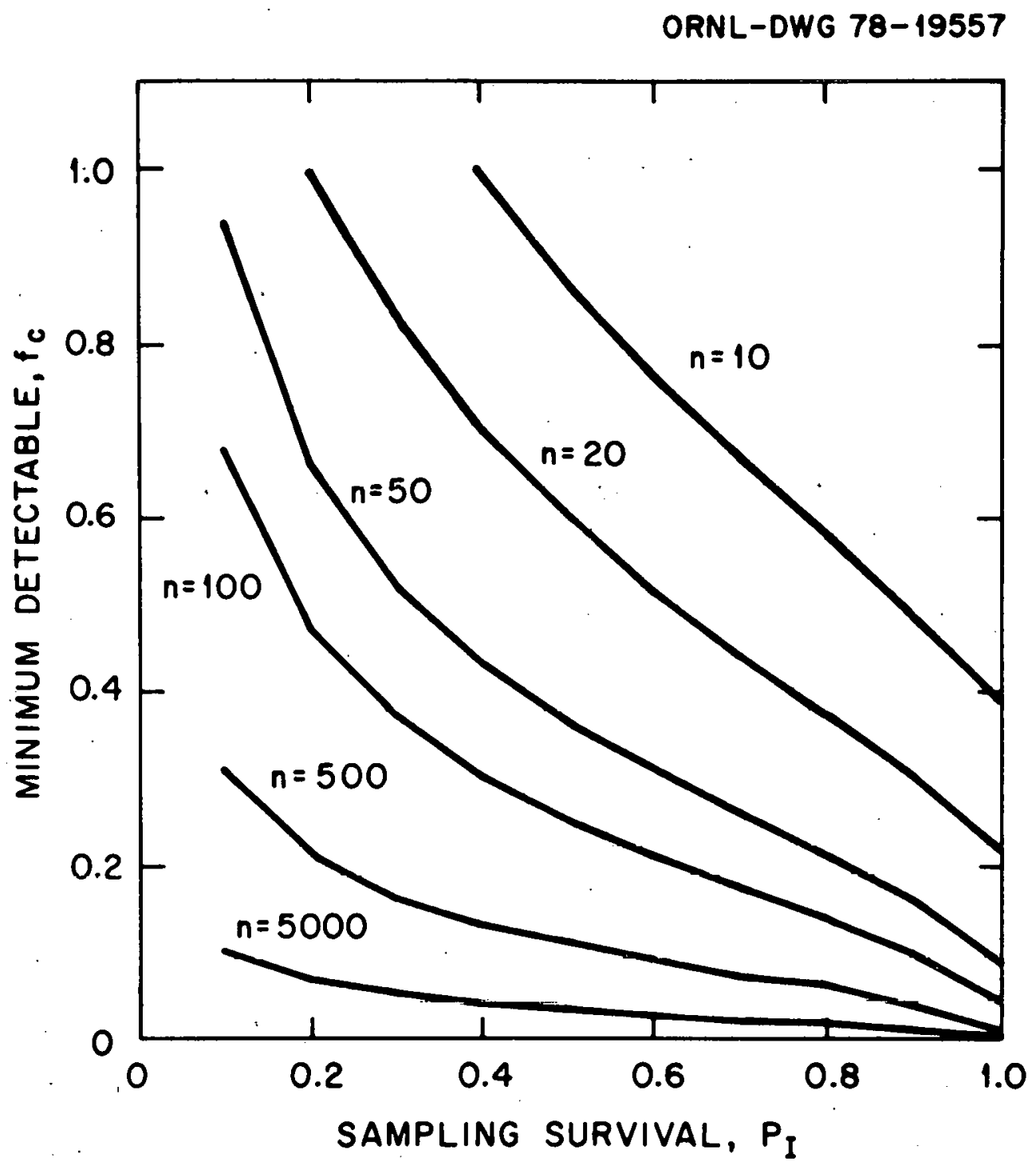

Figure 2. Minimum detectable through-plant entrainment mortality, $f_{C}$, as a function of sampling survival at the intake, $P_{I}$, and sample size, $n$, with $\alpha=0.05$. 
Tables 15 and 16 correspond to Table 5.3-3, respectively, in the 316(b) demonstration (NUS 1976). Table 15 presents our estimates of $f_{c}$ for four zooplankton categories at Prairie Island Nuclear Generating Plant (PINGP) in 1974, while Table 16 presents corresponding data for 1975-76. These data were collected by using separate aliquots for counting dead versus total organisms by categories in both the intake and discharge samples. Thus, it is possible for the estimated probability of survival at the intake $\left(P_{I}\right)$ or at the discharge $\left(P_{D}\right)$ to be negative. For those sampling dates where this situation occurred at either the intake or discharge sample, no calculations were made, and in Tables 15 and 16 the notation NP (not possible) was made. When the test statistic test [Eq. (13)] was not significant at $\alpha=0.05$ (i.e., $Z<1.645)$, NS in Tables 15 and 16 indicates not significant. The values of $f_{c}$ and the limits of the $95 \%$ two-sided confidence intervals (Eq. 7.9 in Fleiss) are given in the remaining cases. It is possible that $f_{c}$ may not be significant at $\alpha=0.05$, but a $95 \%$ confidence interval exists that does not include 0.0 . This result can occur since the test for $H_{0}: f_{c}=0$ is one-sided, while the confidence interval is two-sided. The four categories of zooplankton enumerated are Copepoda, nauplii (a life stage of zooplankton), Cladocera, and Rotifera. Besides calculations based on data from single dates, estimates of $f_{c}$ have also been calculated on a seasonal basis and over all dates. Note the large number of cases in which it was not possible to estimate $f_{c}$, especially in the 1975-76 sampling year (23 out of 44 daily samples of the four categories, Table 16). 
Table 15. Daily, seasonal, and total estimated through-plant entrainment mortality, $f_{C}$, for four categories of zooplankton in 1974 a,b

\begin{tabular}{|c|c|c|c|c|}
\hline Date & Copepoda & Naup 1 i $i$ & $\mathrm{Cladocera}$ & Rotifera \\
\hline $7 / 30$ & $\begin{array}{l}0.81^{\mathrm{C}} \\
(0.73,0.89)\end{array}$ & $\begin{array}{l}0.42^{c} \\
(0.33,0.52)\end{array}$ & NPd & nse \\
\hline $8 / 14$ & $\begin{array}{l}0.41^{c} \\
(0.27,0.55)\end{array}$ & $\begin{array}{l}0.60^{\mathrm{C}} \\
(0.46,0.74)\end{array}$ & NS & $\begin{array}{l}0.35^{c} \\
(0.29,0.41)\end{array}$ \\
\hline $9 / 4$ & NS & NP & NP & $\begin{array}{l}0.31^{\mathrm{c}} \\
(0.14,0.47)\end{array}$ \\
\hline $11 / 21$ & NP & NS & NP & $\begin{array}{l}0.16^{f} \\
(0.01,0.31)\end{array}$ \\
\hline $12 / 18$ & $N P$ & NP & NP & $\begin{array}{l}0.66^{\mathrm{C}} \\
(0.55,0.77)\end{array}$ \\
\hline Sumerg & $\begin{array}{l}0.60 \mathrm{C} \\
(0.52,0.68)\end{array}$ & $\begin{array}{l}0.51 \\
(0.43,0.60)\end{array}$ & NS & $\begin{array}{l}0.32^{c} \\
(0.27,0.38)\end{array}$ \\
\hline Fallh & NP & NS & $N P$ & $\begin{array}{l}0.35^{c} \\
(0.25,0.45)\end{array}$ \\
\hline $\begin{array}{c}\text { Combined } \\
\text { (total) }\end{array}$ & $\begin{array}{l}0.62^{\mathrm{c}} \\
(0.54,0.70)\end{array}$ & $\begin{array}{l}0.45^{c} \\
(0.37,0.53)\end{array}$ & $\begin{array}{l}0.37^{c} \\
(0.15,0.59)\end{array}$ & $\begin{array}{l}0.33^{c} \\
(0.28,0.38)\end{array}$ \\
\hline
\end{tabular}

aNumbers in parentheses represent the limits of the $95 \%$ confidence interval about the $f_{c}$ value given immediately above them. Source: Fle iss, J. L. 1973. Statistical Methods for Rates and Proportions. John Wiley and Sons, New York. 223 pp.

bLetter from Mark Lahtinen (Minnesota Pollution Control Agency) to S. Marshall Adams, May 30, 1978, including as enclosure the sample sizes used to estimate zooplankton mortality due to plant passage at PINGP in 1974.

CSignificant at $\alpha=0.01$.

$d_{N P}=$ not possible to calculate.

$e_{N S}=$ not significant $(\alpha=0.05)$.

fignificant at $\alpha=0.05$.

gIncludes the dates $7 / 30,8 / 14$, and $9 / 4$.

hIncludes the dates $11 / 21$ and $12 / 18$. 
Table 16. Daily, seasonal and total estimated through-plant entrainment mortality, $f_{c}$, for four categories of zooplankton in 1975-76a,b

\begin{tabular}{|c|c|c|c|c|}
\hline Date & Copepoda & Naup Ii i & $\mathrm{Cladocera}$ & Rotifera \\
\hline $6 / 13$ & NPC & NP & NP & $\begin{array}{l}0.16^{d} \\
(0.04,0.28)\end{array}$ \\
\hline $8 / 7$ & NP & NP & NSe & $\begin{array}{l}0.45^{d} \\
(0.39,0.51)\end{array}$ \\
\hline $9 / 8$ & NP & NS & NS & NS \\
\hline $10 / 9$ & NP & $\begin{array}{l}\text { NS } \\
(0.36,1.00)\end{array}$ & NP & NS \\
\hline $11 / 5$ & NP & NS & $N P$ & NP \\
\hline $12 / 0$ & |ंश̄ & MS & Ns & PS \\
\hline $1 / 12$ & NP & NP & $N P$ & NS \\
\hline $2 / 9$ & $\begin{array}{l}1.00^{\mathrm{a}} \\
(1.0,1.0)\end{array}$ & NP & $\mathrm{NP}$ & NP \\
\hline $3 / 4$ & NP & NP & NP & NS \\
\hline $4 / 5$ & $\begin{array}{l}\text { NS } \\
(0.07,0.083)\end{array}$ & $\begin{array}{l}0.51^{d} \\
(0.25,0.78)\end{array}$ & $N P$ & NS \\
\hline $5 / 4$ & $\begin{array}{l}0.48^{d} \\
(0.21,0.75)\end{array}$ & NP & NS & $\begin{array}{l}0.39^{d} \\
(0.34,0.45)\end{array}$ \\
\hline Summerf & NP & $N P$ & NP & NS \\
\hline Fallg & NP & NS & NP & NS _- \\
\hline Wi intei h & NP & NP & NP & N3 \\
\hline Spring 1 & $\begin{array}{l}0.44^{0} \\
(0.21,0.07)\end{array}$ & $N P$ & NS & $\begin{array}{l}0.35^{d} \\
(0.30,0.41)\end{array}$ \\
\hline $\begin{array}{c}\text { Combined } \\
(\text { tntal) }\end{array}$ & NP & $\begin{array}{l}n .9 \text { d d }^{-} \\
(0.92,1.00)\end{array}$ & NS & $\begin{array}{l}0.15 d \\
(0.10,0.19)\end{array}$ \\
\hline
\end{tabular}

aNumbers in parentheses represent the limits of the $95 \%$ confidence interval about the $f \cdot$ value given immediately above them. Source: rleiss, J. L.

1973. Statistical Methods for Rates and Proportions. John Wiley and Sons, New York. $223 \mathrm{pp}$.

bLetter from Larry E. 01 son (Minnesota Pollution Control Agency) to S. Marshall Adams, June 13, 1978, including as enclosure the sample sizes used to estimate zooplankton mortality due to plant passage at PINGP in $1375-76$.

CNP = not possible to calculate.

dsignificant at $\alpha=0.01$.

eNS $=$ not significant $(\alpha=0.05)$.

Includes the dates $6 / 13,8 / 7$ and $9 / 8$.

gInc ludes the dates $10 / 9,11 / 5$ and $12 / 9$.

hIncludes the dates $1 / 12,2 / 9$. and $3 / 4$.

i Includes the dates $4 / 5$ and $5 / 4$. 
Estimates of the sampling survival $\left(P_{I}\right)$ made for the four zooplankton categories for 1974, 1975-76, and overall are presented in Table 17.

Table 17. Sampling survival, $P_{I}$, estimated by category and year

\begin{tabular}{lllll}
\hline & \multicolumn{4}{c}{ Zooplankton category } \\
\cline { 2 - 4 } Year & Copepoda & Nauplii & Cladocera & Rotifera \\
& & & & \\
\hline 1974 & 0.68 & 0.50 & 0.39 & 0.57 \\
$1975-76$ & 0.18 & 0.14 & 0.004 & 0.31 \\
Overal1 & 0.43 & 0.30 & 0.13 & 0.37 \\
& & & & \\
\hline
\end{tabular}

Note that sampling survival was consistently lower in the 1975-76 period as opposed to 1974, and this was also the period when fewer significant $f_{c}^{\prime}$ 's were calculated lespecially with regard to Rotifera). Further note that the Cladocera have lower sampling survival within each year than the other categories and that this is the one category which has no significant nonzero estimates of $f_{c}$ (Table 18). In Table 18 are presented the daily sample sizes at the intakes and discharge stations at PINGP for four zooplankton categories for 1974 through 1976. Using the yearly estimated sampling survivals, $P_{\text {I }}$ (Table 17), and sample sizes in Table 18, one can determine the minimum detectable $f_{C}$. Since $n_{I} n_{D}$ in Table 18, one can overestimate the minimum detectable $f_{C}$ by using the lower of $n_{I}$ or $n_{D}$. We suggest that a reasonable estimate of the minimum detectable $f_{c}$ might be obtained by letting

$$
n=\frac{n_{I}+n_{D}}{2} \text {. }
$$


Table 18. Daily sample sizes at the intake (I) and discharge (D) stations used in calculating through-plant entrainment mortality, $f_{c}$, for four categories of zooplankton in 1974 through 1976 at Prairie Is land Nuclear Generating Plant

\begin{tabular}{|c|c|c|c|c|c|c|c|c|}
\hline \multirow[b]{2}{*}{ Date } & \multicolumn{2}{|c|}{ Copepoda } & \multicolumn{2}{|c|}{ Naup lij } & \multicolumn{2}{|c|}{ Cladocera } & \multicolumn{2}{|c|}{ Rotifera } \\
\hline & I & $D$ & $I$ & $D$ & $I$ & $D$ & I & D \\
\hline \multicolumn{9}{|l|}{ 1974: } \\
\hline $7 . / 30$ & 135 & 115 & 274 & 163 & $4 \dot{4}$ & $18^{a}$ & 84. & - 152 \\
\hline $8 / 14$ & 86 & 111 & 226 & 120 & 36 & 69 & 1019 & 776 \\
\hline $9 / 4$ & 45 & 62 & 194 & $115^{a}$ & $32^{a}$ & $49 a$ & 468 & 628 \\
\hline $11 / 21$ & 9 & $9^{a}$ & 70 & 130 & 7 & $23^{a}$ & 300 & 287 \\
\hline $12 / 18$ & 4 & $1^{a}$ & 27 & $10^{a}$ & 7 & $8^{a}$ & 142 & 113 \\
\hline 1975: & & & & & & . & & \\
\hline $6 / 13$ & $29^{a}$ & $26^{a}$ & $130^{a}$ & $45^{a}$ & $33^{a}$ & $27^{a}$ & 970 & 635 \\
\hline $8 / 7$ & $18^{\mathrm{a}}$ & $39 a$ & 96 & $105^{a}$ & 76 & 99 & 1576 & 1408 \\
\hline $9 / 8$ & $47^{a}$ & $51^{\mathrm{a}}$ & 257 & 146 & 74 & 86 & 1993 & 1674 \\
\hline $10 / 9$ & 20 & $18^{a}$ & 76 & 40 & 14 & $19 a$ & 530 & 356 \\
\hline $11 / 5$ & 19 & $9 \pi$ & 75 & 23 & $2 \sqrt{a} a$ & $9^{a}$ & $301^{a}$ & $\hat{2} 39 a$ \\
\hline $12 / 9$ & $1^{a}$ & $0^{a}$ & 20 & 25 & 3 & 11 & 46 & 346 \\
\hline 1976: & & & & $\cdot$ & & & & \\
\hline $1 / 12$ & $1^{a}$ & 2 & 10 & $11^{a}$ & 1 & $1^{a}$ & 17 & 55 \\
\hline $2 / 9$ & 8 & 12 & 34 & $27 a$ & $0^{a}$ & 1 & 9 & $76^{a}$ \\
\hline $3 / 4$ & 7 & $11^{a}$ & 30 & $13^{a}$ & 1 & $2^{a}$ & 44 & 870 \\
\hline $4 / 5$ & 75 & 42 & 124 & 60 & 21 & $10^{a}$ & 201 & 214 \\
\hline $5 / 4$ & 52 & 67 & 94 & $81^{a}$ & 12 & 16 & 1104 & 1042 \\
\hline
\end{tabular}

aFor these samples the number dead exceeds the total. 
Consider the sampling date, : August 14, 1974, and the zooplankton taxa, Copepoda. Sampling survival in 1974 is given by $P_{I}=0.68$ (Table 17), while the average of the intake and discharge sample sizes is approximately $n=99$ (Table 18). Thus, referring to Table 14 with $n=100$ and $P_{I}=0.7$, the minimum detectable $f_{c}$ is 0.174 . Since Table 15 for this date $(8-14-74)$ gives a calculated $f_{c}$ of 0.41 , it is not surprising that 0.41 was found to be significantly greater than zero. Now consider Cladocera on December 9, 1975, where $n=7$ (Table 17) and $P_{I}=0.004$. If we refer to Table 14 with $n=10$ and $P_{I^{\prime}}=0.1$ (which will underestimate the minimum detectable $f_{c}$ ), then there is no possible value of $f_{c}$ that will reject $H_{0}: f_{c}=0$, so that in Table 16 (Cladocera on December 9, 1975) it is not surprising to have NS (= not significant).

This exercise shows the importance of having a "sufficiently large" sample size (perhaps $n=500$ ) and at least moderate sampling survival (say, $P_{I} \geq 0.5$ ). The staff believes that these are important considerations in the design of a meaningful sampling program for entrainment. It becomes immediately obvious that other than for Rotifera, the sample sizes for determining $f_{c}$ are generally too small (Table 18). Likewise, Table 17 indicates the sampling survival was too low in 1975-76 to detect even moderate values of $f_{c}$ le.g., $\left.f_{c} \geq 0.25\right)$ :

IMPINGEMENT CONSIDERATIONS

The significance of impingement losses was evaluated in the $316(\mathrm{~b})$ demonstration (NUS 1976) by comparing the number of fish impinged to 
the estimated populations for several species. The evaluation of impingement impacts in the $316(b)$ demonstration represents a reasonable impingement assessment based on the quality and type of information available. As indicated in the $316(\mathrm{~b})$ demonstration, there are several problems associated with extrapolation of numbers impinged to effects on populations when these populations are estimated with trawling and tag and release methods (NUS 1976). Determining the significance of impingement impacts relies heavily on the reliability of the estimates of fish population size. There are several problems associated with estimation of fish populations, and these have been discussed in Adams et a1. 1979. Also, the tagging study, conducted for the 316(b) demon stration, was designed to assess the movement of fish and not to estimate population size (NUS 1976).

Recognizing the inherent problems associated with fish population estimates, the numbers of fish impinged during 1975 at Prairie Island were compared to the population estimates given in the $316(\mathrm{~b})$ demonstration (NUS 1976). Table ig shows the major species impinged in 1975, the population estimates for these species given in the 316(b) demonstration, and the percent of the population impinged. Populations of carp and drum in the Mississippi River and Sturgeon Lake were estimated by trawling and impact projections for these species are relatively high (21.3 and $5.7 \%$ respectively). These estimates are probably unrealistic because of the problems with trawling discussed in the 316(b) (NUS 1976). The impact projection for channel catfish is probably also unrealistic because commercial landings indicate ${ }^{\circ} a$ much larger population (NUS 1976) of this species. Estimates for gizzard 
Table 19. Number impinged, population estimates, and percent of the population impinged for the major species in the Mississippi River and Sturgeon Lake near the Prairie Island Nuclear Generating Plant

\begin{tabular}{lccc}
\hline \multicolumn{1}{c}{ Species } & Number impinged & Population estimate & $\begin{array}{c}\% \\
\text { of population } \\
\text { impinged }\end{array}$ \\
\hline Gizzard shad & 70,506 & $6 \times 10^{6^{6}}$ & 1.2 \\
Drum & 3,789 & $66,220^{\mathrm{C}}$ & 5.7 \\
White bass & 2,712 & $173,910^{\mathrm{d}}$ & 1.6 \\
Carp & 427 & $2,002^{\mathrm{C}}$ & 21.3 \\
Sauger & 97 & $609,809 \mathrm{~d}$ & 0.02 \\
Channel catfish & 6,223 & $22,720^{\mathrm{d}}$ & 27.4 \\
\hline
\end{tabular}

aNumber impinged during 1975 from Table 2.5.1-2 of Gustafson et al. $(1975)$.

bpopulation estimate for 1973 in Sturgeon Lake (Anderson 1975).

CBased un Lrawling p. 99 of NUS (1970).

dGased on Peterson population estimate [Table 4.3-14 of NUS (1976)]. 
shad, white bass, and sauger probably represent more realistic population impacts.

In the entrainment section, entrainment losses for white bass and sauger were estimated to range from 0.7 to $24 \%$ (white bass) and 0.3 to $16 \%$ (sauger) of the respective populations. Also, as indicated in this section, entrainment losses for these species could pose a significant problem in the aquatic system near PINGP if the actual loss is at the high end of these predicted ranges. Therefore, considering an additional estimated impact of $1.6 \%$ on the white bass population due to impingement, the probability is increased that a significant impact on the white bass population is occurring due to operation of PINGP.

\section{ALTERNATIVE INTAKE LOCATIONS}

1

The purpose of this section is to determine if the present location of the PINGP intake minimizes ecological impacts. We have addressed this issue by quantitatively comparing biological data collected from the PINGP intake area (mouth of Sturgeon Lake) to data collected from areas near the Mississippi River channel. Entrainment related data compared from both areas include densities of phytoplankton, zooplankton, ichthyoplankton, and primary productivity. Data compared from these two areas related to impingement impacts include fish catch-per-unit-effort and proportions of game vs nongame species.

Ecological data collected at the mouth of Sturgeon Lake was used in this analysis instead of data collected in the intake area adjacent to the plant because the intake area is influenced by recirculation of water from the discharge canal (Stone and Webster 1978, Yeh 1980) and, 
thus, may represent unnatural biological conditions. Thermal additions have been demonstrated to stimulate biological production when ambient water temperatures are cool and to depress production during warmer periods (Talmage and Coutant 1978). Ecological data collected near the mouth of Sturgeon Lake should closely represent baseline ecological conditions near the intake area because the source of intake water for PINGS is mainly from Sturgeon Lake (Baker 1975, Sluzha 1974).

\section{Phytoplankton}

Phytoplankton data used in the analysis were collected by the utility during 1974-1976 and consisted of 21 samples at each station in 1974, 13 samples in 1975, and 12 in 1976. Samples were usually taken once each month but more frequently in the warmer months. Phytoplankton data compared were total density expressed as $\mathrm{mg} / \mathrm{liter}$ wet wt. Data expressed as weight instead of number are used in the analysis because ecosystem energetics and trophic relationships are based on weight or biomass (Wilhm 1967).

The temporal distribution of the observed differences in phytoplankton density between. Sturgeon Lake and the river are shown in Fig. 3. These differences were calculated by substracting the natural logarithm of the Sturgeon Lake densities from the logarithm of the river densities at each sampling period. During 1974, densities were consistently higher in Sturgeon Lake than those in the river, but during 1975 and 1976 no consistent differences seemed to be evident (Fig. 4). The only consistent pattern between 1975 and 1976 is the Sturgeon Lake values which are higher than those in the river during part of the summer and early fall of both ycars. 


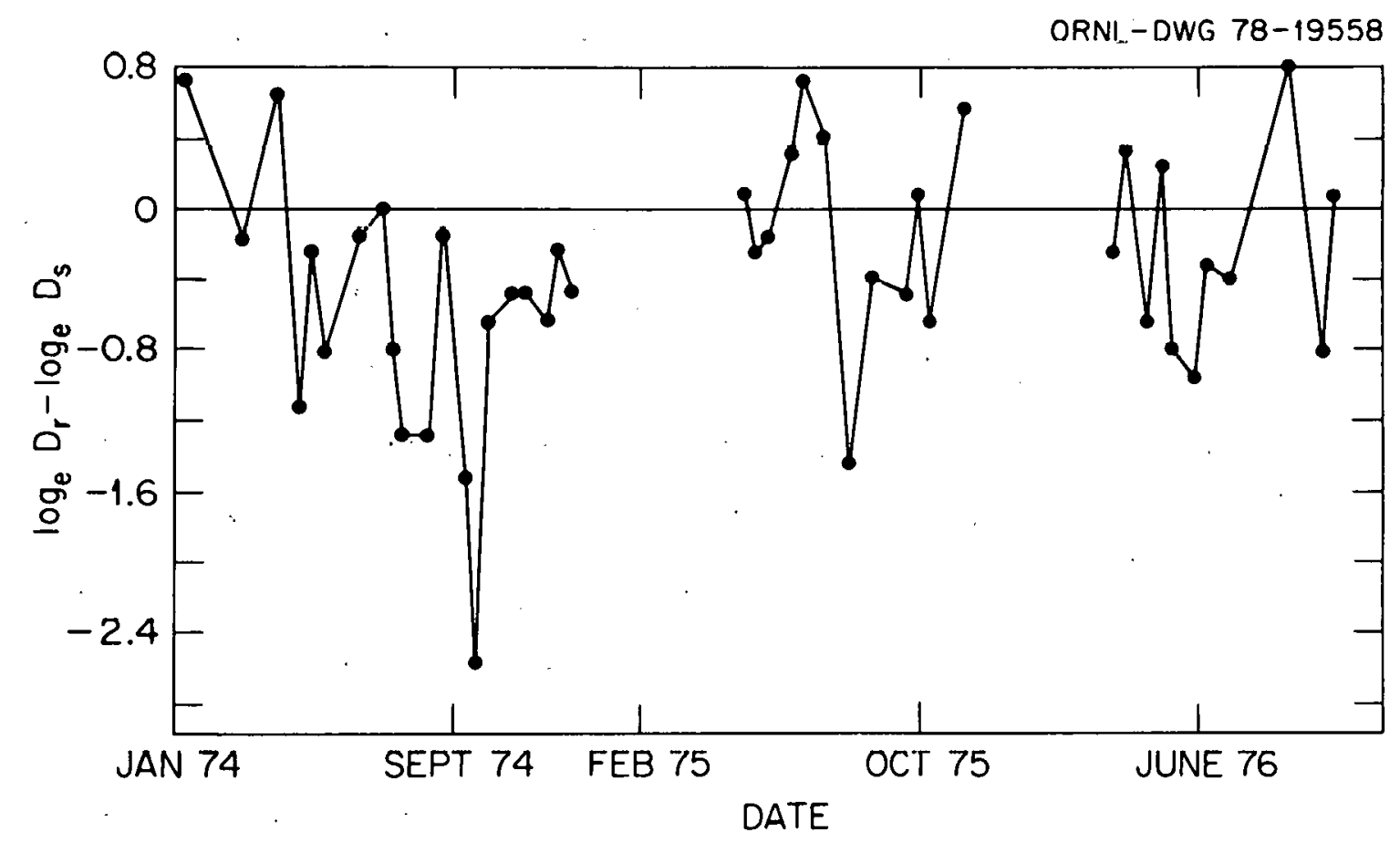

Figure 3. Temporal distribution of the differences in the natural logarithms of Sturgeon Lake $\left(D_{S}\right)$ and the Mississippi River $\left(D_{r}\right)$ phytoplankton densities. 


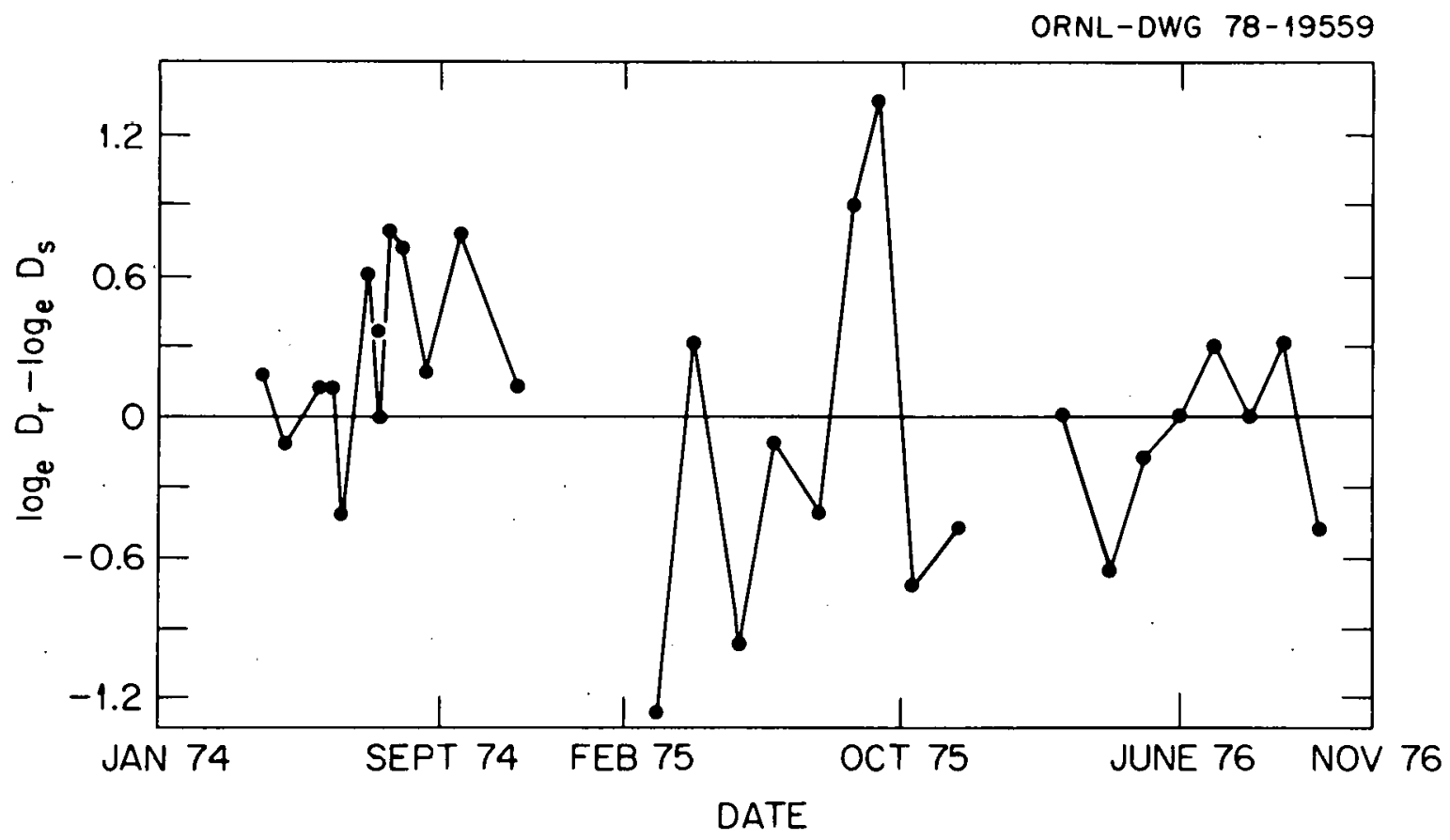

Figure 4. Temporal distribution of the differences in the natural logarithms of Sturgeon Lake $\left(D_{s}\right)$ and the Mississippi River $\left(D_{r}\right)$ zooplankton densities. 
The observed phytoplankton densities for each sampling period were transformed by natural logarithms to meet the assumption of normality. A student's t-test was conducted to test the hypothesis of equal densities at the two sites. The estimated average difference in phytoplankton densities between the river and Sturgeon Lake for 1974-1976 is shown in Table 20. In 1974, phytoplankton densities were significantly lower in the river than those in the mouth of Sturgeon Lake (Table 20). In 1975 and 1976 no significant difference in phytoplankton densities were shown to exist between the two stations. When all three years are considered together, however, density in the river appears to be significantly lower than that in Sturgeon Lake.

Based on the analysis of the 1974 and combined (1974-1976) phytoplankton data the decision relative to impact minimization on phytoplankton would be to locate the intake in the Mississippi River instead of at the present site. Based on the 1975 and 1976 data, the conclusion would be that the location of the intake makes no difference in terms of impact minimization.

Any true differences in plankton densities between stations and years may be masked by large natural variations in densities caused by periodic high river flows in the Mississippi. Phytoplankton, however, because of their relatively fast turnover and recovery rates, may be a better indicator of natural conditions in the river than other organisms (such as zooplankton) with slower turnover rates. For example, the estimated variance $\left(\hat{\sigma}^{2}\right)$ between years for phytoplankton (Table 20) are very similar, possibly indicating that the large variations in phytoplankton densities, which may have occurred due to 
Table 20. Estimated average differences in phytoplankton density between the Mississippi River $\left(D_{r}\right)^{a}$ and Sturgeon Lake $\left(D_{S}\right)^{b}$ for 1974-1976 and all years combined

\begin{tabular}{lccrr}
\hline & \multicolumn{3}{c}{ Year } & \\
\cline { 2 - 4 } & 1974 & 1975 & 1976 & $\begin{array}{l}1974-76 \\
\text { combined }\end{array}$ \\
\hline$\overline{D_{r}-D_{s}}$ & -0.595 & -0.095 & -0.235 & -0.363 \\
$\hat{\sigma}^{c}$ & 0.167 & 0.173 & 0.166 & 0.106 \\
$d f$ & 19 & 11 & 10 & 42 \\
$\mathrm{t}$ & -3.57 & -0.55 & -1.41 & -3.4 \\
Prob. $>|\mathrm{t}|$ & 0.002 & 0.593 & 0.189 & 0.002 \\
\hline
\end{tabular}

${ }^{a} D_{r}=\log _{e}$ (density in river +1$)$.

$\mathrm{b}_{D_{S}}=\log _{e}$ (density in Sturgeon Lake +1 ).

$c_{\hat{u}} 2=$ estimaled variance of $\overline{D_{r}-D_{s}}$. 
high river flows, could have been partially masked by the high biological turnover rates. Even though phytoplankton densities could have been substantially reduced for short periods (hours or days) during high river flows, populations could have recovered between the monthly or biweekly sampling periods. For example, in 1976, the only year for which daily river flows were available, high river flows occurred from March 30 to April 10. The last phytoplankton sampling date before this high flow was March 24 when 4.09 and $3.2 \mathrm{mg} / 1$ iter of phytoplankton were recorded at Sturgeon Lake and the river respectively. River flow through lock and dam no. 3 below the plant on this date was 24,000 cfs. During the next sample period on April 6, standing crops were 1.56 and $2.15 \mathrm{mg} / \mathrm{liter}$ respectively at a river flow of $72,000 \mathrm{cfs}$. On April 21, following the high flows, the densities were 13.76 and 7.34 , respectively, at a river flow of $28,000 \mathrm{cfs}$. Even though naturally increasing water temperatures and light levels were probably responsible in part for the large observed increase in phytoplankton densities after April 6, 1976, this rapid recovery of phytoplankton could also be attributed to the high turnover rates and reproduction which is characteristic of this trophic group.

\section{Primary productivity}

Primary production data were available for 1974 and 1975 from the PINGP annual monitoring reports. In 1974, 13 measurements were taken from August to December; and in 1975, 15 measurements were taken from May-September. Data were taken in Sturgeon Lake and the Mississippi River and are expressed as net primary production rates. 
The estimated average difference in the untransformed (data was not transformed because the normality assumption was met with the untransformed datal data from the two areas is presented in Table 21. As was suggested by analysis of the phytoplankton density data, primary productivity in Sturgeon Lake was significantly higher $(P>t=0.02)$ than the river in 1974. In 1975, productivity was higher in Sturgeon Lake, but not significantly $(P>t=0.65)$. When data for both years were combined, Sturgeon Lake exhibited a higher productivity at the 0.03 level (Table 21 ).

Considering the 1974 and combined 1974 and 1975 primary productivity data, the conclusion would be to locate the intake in the river to minimize entrainment impacts on primary productivity. If the 1975 data were considered, however, placement of the intake would make no difference in terms of minimization of impact on primary productivity.

\section{Zooplankton}

Zooplankton density data, collected monthly between 1974-1976, was compared between Sturgeon Lake and the river. As in the phytoplankton analysis, data were first transformed to natural logarithms before testing for possible differences in the two areas. A plot of the temporal differences in densities between areas show that zooplankton densities in the river may have been higher than Sturgeon Lake during 1974, but in 1976 no trends in the differences are evident (Fig. 4). The differences in the densities were highly variable during 1975 , possibly indicating effects of high periodic river flows on the zooplankton community during that year. 
Tabie 21. Estimated average differences in primary productivity between the Mississippi River $\left(D_{r}\right)^{a}$ and Sturgeon Lake $\left(D_{S}\right)^{b}$ for 1974-1975 and for these years combined

\begin{tabular}{lccc}
\hline & \multicolumn{2}{c}{ Year } \\
\cline { 2 - 3 } & 1974 & 1975 & $\begin{array}{c}1974-75 \\
\text { comb ined }\end{array}$ \\
\hline$D_{r}-D_{S}$ & -0.882 & -0.104 & -0.453 \\
$\partial 2^{c}$ & 0.31 & 0.229 & 0.196 \\
$d f$ & 12 & 15 & 28 \\
$t$ & -2.84 & -0.47 & -2.31 \\
Prob. $|>| t$ & 0.02 & 0.65 & 0.03 \\
\hline
\end{tabular}

$\mathrm{aD}_{r}=\log _{\mathrm{e}}$ (primary productivity in river +1$)$.

$\mathrm{b}_{\mathrm{D}_{\mathrm{S}}}=\log _{\mathrm{e}}$ (primary productivity in Sturgeon Lake +1$)$.

$\mathrm{c}_{\hat{\sigma}^{2}}=$ estimated variance of $\overline{D_{r}=D_{S}}$. 
Table 22 indicates that in 1974 densities of zooplankton in Sturgeon Lake were significantly higher $(P>t=0.02)$, and in 1975 and 1976 very little differences occurred between the two stations. If a decision based on the 1974 zooplankton data were to be made relative to intake location, then the decision would be that the present location minimizes zooplankton entrainment impacts. A decision based on the 1975 or 1976 data would be that the location makes no difference in terms of impact minimization on zooplankton.

In contrast to the phytoplankton data, the year-to-year variation of the zooplankton differences $\left(\hat{\sigma}^{2}\right)$ for the two areas are considerable (phytoplankton range $=0.07$, zooplankton range $=0.308)$ (Tables 20 and 22), possibly indicating that the large variations in densities between years may have been due to river flow variations between years. For example, river flows in 1975 were much higher and variable than those in 1974 or 1976 (Fig. 5), probably accounting for the large variations in differences between stations during 1975 (Table 22). During 1974 and 1976 when river flows were less variable, variances in zooplankton were much smaller (Table 22). The larger range in variances for zooplankton compared to phytoplankton densities may reflect, in part, differences in turnover rates of the two groups. Zooplankton have much longer reproductive cycles than phytoplankton, therefore zooplankton would have less time than phytoplankton for recovery between successive sampling intervals that follow high river flows and washouts of organisms (such as may have occurred in 1975). To place more reliability, therefore, on results related to ànalysis of alternative intake locations, decisions should be based on data which are repre- 
Table 22. Estimated average difference in zooplankton densities (weights) between the Mississippi River $\left(D_{r}\right)^{\text {a }}$ and sluryeurl Lake $\left(D_{S}\right)^{\text {b }}$ for 1974-1976 and all years combined

\begin{tabular}{lrrrc}
\hline & 1974 & 1975 & 1976 & $\begin{array}{c}1974-76 \\
\text { comb ined }\end{array}$ \\
\hline$D_{r}-D_{S}$ & & 0.262 & -0.161 & -0.091 \\
$\hat{\sigma}^{2}$ & 0.066 & 0.368 & 0.060 \\
df & $1 . ?$ & .8 & 7 \\
Prob. $>|t|$ & 0.02 & 0.06 & 0.48 \\
\hline
\end{tabular}

$a_{D_{r}}=\log _{e}$ (zooplankton density in river +1$)$, $b_{U_{S}}=\log _{e}$ (zooplankton denșity in Sturgeon Lake +1 ). $\hat{\sigma}^{2}=$ estimated variance of $\hat{\sigma}^{2}$. 
ORNL-DWG 78-19560

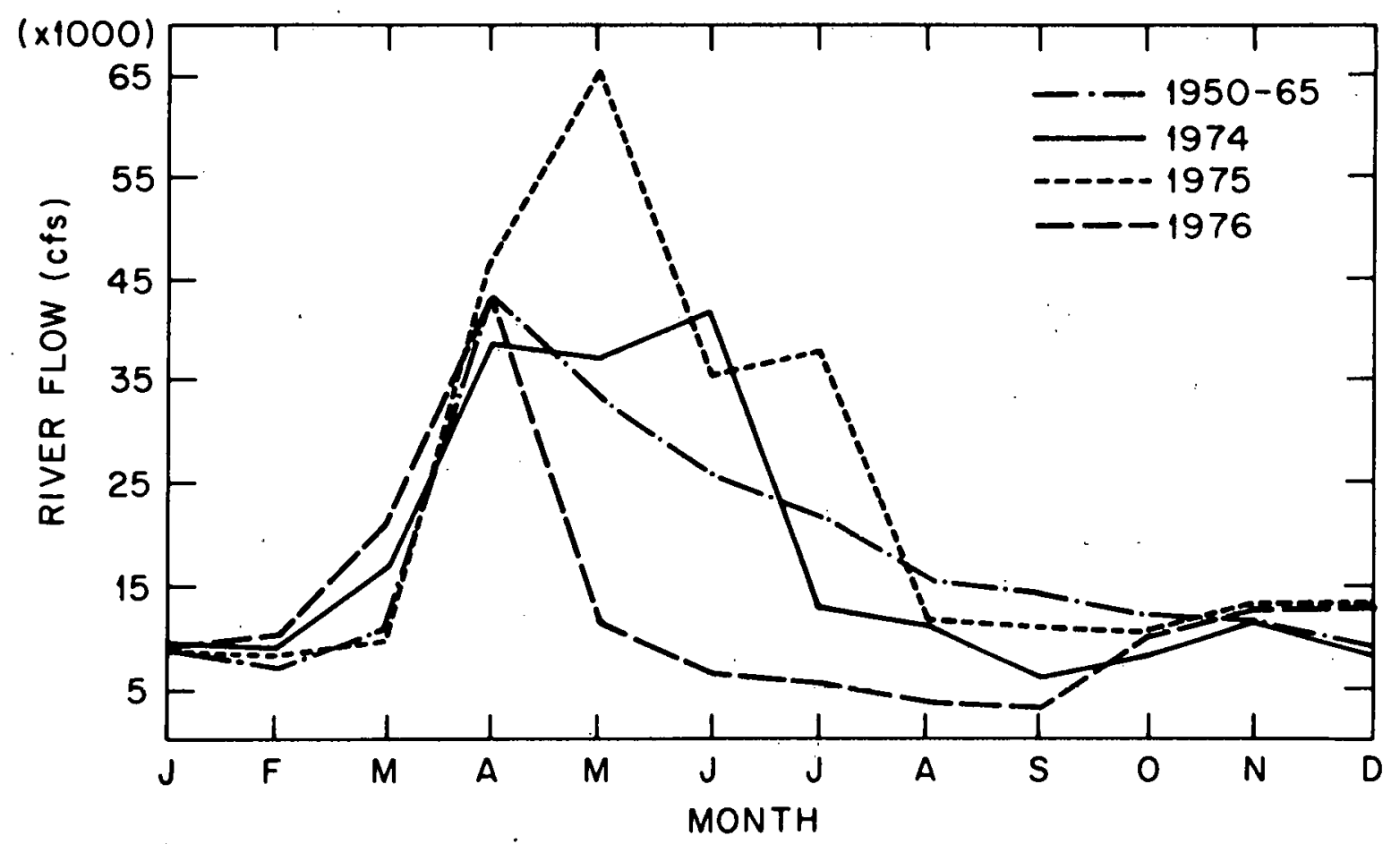

Figure 5. Average monthly river flows of the Mississippi River at Prescott for 1974-1976 and the historical averages for 1950-1965. 
sentative of average river flow years during the periods when biological production is the highest (i.e., April-July in most temporal systems). Low flow years may also represent "steady state" ecological conditions in which some reliability may be placed on intrepretation of plankton data; i.e., high periodic river flows do not occur during low flow years (in which cases washout and dilution of plankton are minimal), providing for meaningful data intrepretation.

F1sh

Fish data used in this analysis were collected by electroshocking at Minnesota Department of Natural Resources stations 1-7 (Sturgeon Lake) and 2-9 (main river) during June, August, and September of 1974 and 1975 (MDNR 1978). 1 Electroshocking data were used in this analysis because trawl and trapnet data were not available from the main river, and seining data is biased for small shore-zone fishes such as minnows and shiners. Sturgeon Lake station 1-9, nearest the PINGP intake, was not used in this analysis because of the possible influence of the discharge canal recirculation water on the intake area (see phytoplankton section). Two main comparisons were conducted between stations; catch-per-unit-effort (CPUE) and proportions of game vs nongame species.

A comparison of the CPUE for the 1974 and 1975 data combined indicates no significant differences (Table 23) between the two stations $(P>t=0.37)$. Results of this comparison should be interpreted

IRaw data supplied to ORNL by Minnesota Department of Natural Resources. 
Table 23. Catch-per-unit-effort (number per 15-min sample) by electroshocking in Sturgeon Lake (stat. 1-7) and the main river (stat. 2-9) for three months in 1974 and 1975

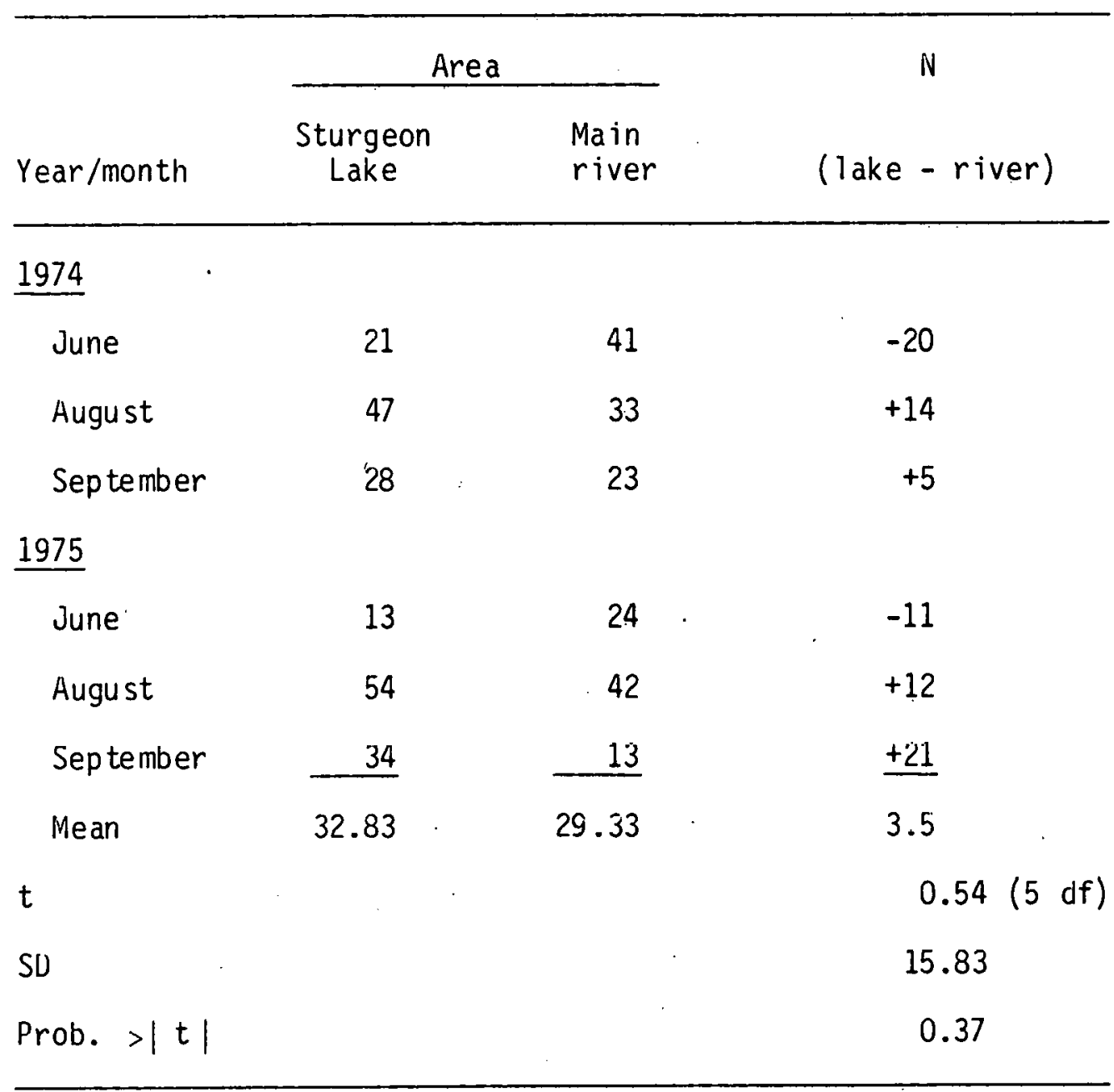


with caution if they are to be the basis of decisions relative to intake locations because of (1) the small sample sizes involved, (2) the high coefficient of variation (450\%) which indicates wide variability in the data (i.e., the standard deviation is 4.5 times the mean), and (3) the problems associated with the quantification of electroshocking data (e.g., shocked fish may sink to the bottom and be overlooked and bottom fish may avoid the gearl.

Another comparison between stations involved the proportion of game vs nongame species. The species designated as game were bluegill, sauger, smallmouth, white, rock bass, drum, crappie, walleye, yellow perch, channel catfish, and sunfish. Nongame species were carp, carpsucker, chubs, buffalo, log perch, redhorse, and gar. Gizzard shad, shiners, and minnows were labeled as forage species.

The numbers of game and nongame fish caught in 1974, in 1975, and for the years 1974 and 1975 combined, as well as the ratio of game fish to the total fish caught are given in Table 24. A chi-square test of proportions indicated that there was no significant difference between stations 2-9 and 1-7 (Table 24) for 1975 or for the 1974 and 1975 combined data $(P>t=0.05)$. In 1974, however, stations $2-9$ had a significantly higher proportion of game fish $(P>t=0.01)$ than stations 1-7 (Table 24). More smallmouth bass were caught in the river than in sturgeon Lake during 1974 which accounted for most of the observed difference in the ratio of game to nongame species between the two stations.

Prior to the analysis and comparison of these fish data, it was hypothesized that Sturgeon Lake may have a higher proportion of game 
Table 24. Number of game and nongame fish and the ratio of game $f$ ish to total fish caught at stations 1-7 (Sturgeon Lake) and 2-9 (Main River) in 1974, 1975, and for 1974 and 1975 combined

\begin{tabular}{lcccc}
\hline Stations & Game & Nongame & Total & Game/tota \\
\hline & & & $\underline{1974}$ & \\
$1-7$ & 40 & 56 & 96 & 0.42 \\
$2-9$ & 62 & 35 & 97 & 0.64
\end{tabular}

$9.59 a$

$\underline{1975}$

$\begin{array}{rrrrr}1-7 & 26 & 75 & 101 & 0.26 \\ 2-9 & 27 & 52 & 79 & 0.34\end{array}$

1.52 NSb

$1974 \& 1975$

$1-7$

66

131

197

0.34

$2-9$

89

87

176

0.50

aHo: stations $1-7$ = stations $2-9$.

bSignificant at 0.01 leve.1.

CNot significant. 
fish than the river because of its apparent ecological function as a fish spawning and feeding area. Analysis based on the electroshocking data (Table 24), however, does not provide a statistical basis for concluding that Sturgeon Lake has a higher CPUE of fish or that it has a higher proportion of game fish than the river. Due to the small sample sizes involved and the problems with quantification of electroshocking data, the results of these comparisons should be intrepreted with caution. Decisions, therefore, relative to the best location of the intake for minimizing fish impingement should be based on more reliable and quantitative data than those available for this analysis.

Ichthyoplankton

A short-term intensive ichthyoplankton survey was conducted between 6-17 June 1978 at three stations in the vicinity of PINGS. Station I was located in the main channel of the Mississippi northeast. of the plant, station II near the main channel at the end of the dredged intake cand, and station III at the mouth of Sturgeon Lake slightly north of the present intake. Samples were taken between midnight and $4 \mathrm{a} . \mathrm{m}$. On six days between June 6 and 17, 1978. Two oblique tows and two replicates per tows were taken at each station on each sampling day using a 560-mesh net. Eggs and.larvae were identified to the lowest practical taxonomic level and reported as number of eggs or larval stage per unit amount of water sampled $\left(\right.$ no. $\left./ \mathrm{m}^{3}\right)$.

For the purpose of comparing the densities of larvae between stations, all three of the reported larval stages (proto, mesa, meta) were combined as total larvae. All taxonomic levels were combined into ten 
categories for computational purposes. This categorization was necessary because some taxonomic units were represented by only a few individuals, while others such as sunfishes, crappie, and the centrachids could be systematically combined into one group. These categories are:

1. Dorosoma cepedianum (gizzard shad)

2. Cyprinidae (minnows and carps)

3. Morone chrysops (white bass)

4. Pomoxis, centrarchidae, and Lepomis (crappie and sunfish)

5. Aplodinotus grunniens (freshwater drum)

6. Unidentified eggs and larvae

7. Cyprinus carpio (common carp)

8. Catostomidae (suckers)

9. Percidae (perch)

10. Other (mainly Notopis sp.)

Categories 5 and 8 include eggs and larvae, while the remainder are larvae only.

Results of stations I and III comparisons

Table 25 shows the total number of larvae (or eggs) caught during the entire sampling period and the number of replicates (maximum $=24$ ) in which each category appeared for each station. Gizzard shad (1) and drum (5) not only appeared in the highest density at each station but were present in every sample taken.

An analysis of variance on the total larvae and eggs (log transformed densities) caught at stations I and III for all dates (Tables 26 and 27) indicates that total larvae are significantly higher at 
Table 25. Total number of larvae (or eggs when indicated) caught during the June 6-17 survey and the number of replicates (maximum $=24$ ) in which each category appears for each station

\begin{tabular}{|c|c|c|c|c|c|c|c|}
\hline & & Total & number & caught & Number of & replicates & s present \\
\hline & Cateqory & I & I I & $\overline{\text { III }}$ & I & II & III \\
\hline 1. & Gizzard shad & 677 & 567 & 8778 & 24 & 24 & 24 \\
\hline 2. & Cyprinidae & 361 & 35 & 56 & 22 & 16 & 20 \\
\hline 3. & White bass & 46 & 81 & 524 & 15 & 16 & 24 \\
\hline 4. & $\begin{array}{l}\text { Sunfish, } \\
\text { crappie }\end{array}$ & 16 & 12 & 72 & 24 & 13 & 18 \\
\hline 5. & $\begin{array}{l}\text { Drum } \\
\text { (eggs) }\end{array}$ & $\begin{array}{r}659 \\
1836\end{array}$ & $\begin{array}{r}418 \\
1752\end{array}$ & $\begin{array}{r}609 \\
1572\end{array}$ & $\begin{array}{r}24 \\
.24\end{array}$ & $\begin{array}{l}24 \\
21\end{array}$ & $\begin{array}{l}24 \\
21\end{array}$ \\
\hline 6. & $\begin{array}{l}\text { Unidentified } \\
\text { (eggs) }\end{array}$ & $\begin{array}{r}10 \\
273\end{array}$ & $\begin{array}{l}41 \\
13\end{array}$ & $\begin{array}{l}10 \\
13\end{array}$ & $\begin{array}{r}6 \\
24\end{array}$ & $\begin{array}{l}7 \\
4\end{array}$ & $\begin{array}{r}2 \\
6\end{array}$ \\
\hline 7. & $\begin{array}{l}\text { Carp } \\
\text { (cgg) }\end{array}$ & $\begin{array}{l}92 \\
12\end{array}$ & $\begin{array}{r}418 \\
-\quad 0\end{array}$ & $\begin{array}{r}598 \\
0\end{array}$ & $\begin{array}{r}13 \\
2\end{array}$ & $\begin{array}{r}23 \\
0\end{array}$ & $\begin{array}{l}21 \\
0\end{array}$ \\
\hline 8. & Catostomidae & 61 & 27 & 37 & 15 & 14 & 14 \\
\hline 9. & Percidae & 4 & 1 & 25 & 4 & 1 & 10 \\
\hline 10 . & Other & 23 & 10 & 217 & 3 & 6 & 17 \\
\hline
\end{tabular}


Table 26. Analysis of variancea for all larvae collected at stations I and III during june 6-17

\begin{tabular}{|c|c|c|c|c|c|}
\hline \multicolumn{2}{|c|}{ Source } & $d f$ & SS & $\mathrm{F}$ & $F$ \\
\hline \multicolumn{2}{|l|}{ Station } & 1 & 9.832 & 343.17 & 0.0001 \\
\hline \multicolumn{2}{|l|}{ Day } & 5 & 3.058 & 21.34 & 0.0001 \\
\hline \multicolumn{2}{|c|}{ Station $x$ day } & 5 & 2.913 & 20.34 & 0.0001 \\
\hline \multicolumn{2}{|l|}{ Error } & 36 & 1.031 & & \\
\hline \multicolumn{2}{|c|}{ Total (corrected) } & 47 & 16.835 & & \\
\hline Station & Mean & & & & . \\
\hline I I I & $\begin{array}{l}0.472 \\
1.377\end{array}$ & & & & \\
\hline \multicolumn{6}{|c|}{ Least-square difference $=0.905$} \\
\hline \multicolumn{6}{|c|}{ Critical $\alpha$ level $=0.0001$} \\
\hline
\end{tabular}

aAll densities $(x)$ transformed by $y=\log _{e}(x+1)$.

Table 27. Analys is of variancea for all eggs collected at stations I and III during June 6-17

\begin{tabular}{lrlll}
\hline \multicolumn{1}{c}{ Source } & df & SS & $F$ & $P>F$ \\
\hline Station & 1 & 0.241 & 26.63 & 0.0001 \\
Day & 5 & 2.686 & 59.35 & 0.0001 \\
Station x day & 5 & 1.707 & 37.72 & 0.0001 \\
Error & 36 & 0.326 & & \\
Total (corrected) & 47 & 4.96 & & \\
& & & & \\
Station Mean & & & & \\
III $\quad 0.498$ & & & \\
Least-square difference $=0.142$ & \\
Critical $\alpha$ level = 0.0001 &
\end{tabular}

$\left.a_{A}\right]$ densities $(x)$ transformed by $y=\log _{e}(x+1)$. 
station III (Sturgeon Lake) than at station I (river), while total eggs are significantly higher in the river.

A comparison of the total larval densities between stations for each of the six sampling periods shows that except for the last sampling day (June 18), the total larval densities were significantly higher in Sturgeon Lake during each sampling period (Table 28).

The average densities (average of $\log$ transformed data) for each group of larvae were also compared between station I and III (Table 29). Categories 1 (gizzard shad), 3 (white bass), 4 (sunfish and crappie), 7 (carp), 9 (perch), and 10 (other) are significantly higher in Sturgeon Lake than those in the river. Only category 2 (cyprinidae) was significantly higher in the river.

\section{Discussion}

Because of the short sampling period of this survey (two weeks) and the small number of larvae collected for most categories (Table 25), the peak spawning period for many species may have been missed. The May 15- September 4, 1975 ichthyoplankton survey, which was conducted at the PINGP bar rack station, indicated that the peak 1975 density of most larvae occurred from midto late-May, with smaller secondary peaks occurring for some species in mid-summer (NUS 1976). For example, the peak for drum eggs was May 29 with a secondary peak on June 19. May 29 was also the peak larval period that year for white bass, Percidae, emerald shiner, gizzard shad, crappie, and Catostomidae. Cyprinidac and Lepomis larvae were the only categories that peaked during July. Eddy and Underhill (1974) also indicate that most 
Table 28. Statistical comparison of the average larval densitiesa between stations I and III for each sampling date

\begin{tabular}{|c|c|c|c|c|c|}
\hline \multirow[b]{2}{*}{$\begin{array}{l}\text { Samp ling } \\
\text { date }\end{array}$} & \multicolumn{2}{|c|}{$\begin{array}{l}\text { Mississippi River } \\
\text { (station I) } \\
\end{array}$} & \multicolumn{2}{|c|}{$\begin{array}{l}\text { Sturgeon Lake } \\
\text { (station III) }\end{array}$} & \multirow[b]{2}{*}{$\begin{array}{l}\text { Probability } \\
\text { I III }\end{array}$} \\
\hline & No./m & SE & No./m & SE & \\
\hline June 6 & 0.4016 & 0.0665 & 1.0453 & 0.0665 & 0.0005 \\
\hline June 8 & 0.5199 & 0.0386 & 1.3513 & 0.0386 & 0.0001 \\
\hline June 10 & 0.5256 & 0.0407 & 2.3652 & 0.0407 & 0.0001 \\
\hline June 13 & 0.2723 & 0.0611 & 1.1684 & 0.0611 & 0.0001 \\
\hline June 15 & 0.4908 & 0.0238 & 0.9826 & 0.0238 & 0.0001 \\
\hline \multirow[t]{2}{*}{ June 18} & 0.8632 & 0.1764 & 1.0638 & 0.1764 & 0.4520 \\
\hline & \multicolumn{4}{|c|}{ station III } & \\
\hline
\end{tabular}

aAll densities $(x)$ transformed by $y=\log _{e}(x+1)$. 
Table 29. Statistical comparison of the larval densities $(\log s)^{a}$ between station I (river) and station III (Sturgeon Lake) for each of the ten categories of fish

\begin{tabular}{ccccc}
\hline & \multicolumn{2}{c}{$\bar{x}$ No./m } & & \\
\cline { 2 - 5 } $\begin{array}{c}\text { Category } \\
\text { of fish }\end{array}$ & I & III & $\alpha^{\mathrm{b}}$ & I-IIIC \\
\hline 1 & 0.1994 & 1.1852 & 0.0010 & - \\
2 & 0.0952 & 0.0178 & 0.0160 & + \\
3 & 0.0157 & 0.1406 & 0.0001 & - \\
4 & 0.0054 & 0.0235 & 0.0005 & - \\
5 & 0.1914 & 0.1754 & 0.4931 & 0 \\
6 & 0.0034 & 0.0031 & 0.9198 & 0 \\
7 & 0.0295 & 0.1561 & 0.0001 & - \\
8 & 0.020 & 0.0117 & 0.0082 & 0 \\
9 & 0.0013 & 0.0080 & 0.0009 & - \\
10 & 0.0075 & 0.006 & 0.0001 & - \\
\hline
\end{tabular}

$a_{\text {Average of the logged densities }}=\frac{1}{n} \sum_{i=1}^{n} \log \left(x_{i}+1\right)$, where $x_{j}=$ observed density (No. $\left./ \mathrm{m}^{3}\right)$ and $n=$ number of samples (24)..

bProbability $[|t|>0] ; H O$ : Station I = station III.

$c_{+}=$River significantly higher than Sturgeon Lake.

- = River significantly lower than Sturgeon Lake.

$0=$ No significant difference between river and lake. 
of these groups spawn in Minnesota waters during the spring (1ate April to early June).

The spawning peaks of two important game species, walleye and sauger, were probably missed during the 1978 sampling. During the 1975 bar rack survey, Stizostedion spp. larvae had their highest densities during the last two weeks of May (NUS 1976). According to Eddy and Underhill (1974) sauger spawn in April and May in shallow water and walleye spawn shortly after the spring thaw, also in shallow water.

- Because the peak spawning periods of some species may have not been included in the 1978 survey, final decisions relative to placement of the intake should be based on a more extensive data base. This is particularly true of sauger and walleye (percidae) and the sunfish and crappie (group 4). Data for gizzard shad, cyprinidae, white bass, drum, and carp appears sufficient, however, for making some tentative conclusions.

of the above groups, only gizzard shad, white bass, and carp larvae were significantly higher in Sturgeon Lake. Cyprinidae were significantly higher in the river, while no significant difference between the river and Sturgeon Lake were indicated for drum eggs and larvae and sucker larvae. According to Eddy and Underhill (1974) all of the above species spawn in shallow water. River habitats, such as those occurring in the main channel of the Mississippi near the plant, do not appear to be favorable spawning habitats for the above groups.

It would appear, therefore, from the analysis and interpretation of these data, that to minimize impacts to gizzard shad, white bass, and carp, the intake should be located in the river. For drum and 
suckers, the location would make no difference in terms of impact minimization while, for the cyprinids, placement of the intake in an area other than the river is preferable. Placement of the intake in the river may also tend to favor impact minimization on the sunfishes, crappie, and percidae.

Concern for impact minimization to the gizzard shad population does not seem ecologically justified because of the abundance and prolific nature of this species. As stated by Eddy and Underhill (1974), if gizzard shad were not preyed upon, these highly prolific fish would rapidly become very abundant. Similarily, carp and the cyprinids are ubiquitous and prolific fishes; therefore, recommendations to relocate the intake for the benefit of these species does not seem justified.

There does appear, however, to be a potential problem with white bass. The previous section related to PINGP entrainment impacts, projected that 1 to $24 \%$ of the white bass population in the area near PINGP may be affected due to larval entrainment through the existing intake system. If this represents a significant effect on this population of game fish, then a decision to relocate the intake to minimize impacts on this species warrants consideration.

\section{Results of stations I, II, III comparisons}

The total eggs, total larvae, and larvae of all ten categories were compared between stations I, II, and III using Duncan's multiple range test at an alpha $(\alpha)$ level of 0.05 . Table 30 indicates that for total eggs, stations II and III are not significantly different; however, station I (river) is significantly higher than both II and 
Table 30. Analys is of variance and Duncan's Multiple Range Test for all eggs collected at stations I, II, and III during June 6-17, 1978

\begin{tabular}{lcccc}
\hline Source & df & SS & $F$ & $P>F$ \\
\hline Station & 2 & 0.0299 & 17.02 & 0.001 \\
Day & 5 & 3.7059 & 100.97 & 0.001 \\
Station x day & 10 & 2.6557 & 36.18 & 0.001 \\
Error & 54 & 0.3964 & \\
Total (corrected) & 71 & 7.0078 & \\
& Duncan's Multiple Range Test $(\alpha=0.05)$ & \\
\cline { 2 - 5 } & \multicolumn{5}{c}{ Station (Mean) } \\
& II(0.4977) & II(0.4032) & III (0.3560) \\
\hline
\end{tabular}


III. Conversely, for total larvae, station III is significantly higher than either stations I or II which are similar (Table 31 ).

The average densities (log-transformed) of each category of larvae were also compared between stations I to III (Table 32). Gizzard shad, white bass, sunfish and crappie, percidae, and other larvae at stations I and II were not significantly different, but both stations were significantly lower than station III. The densities of cyprinidae and catostomidae at station II were not different from those at station III but were significantly lower than that at station 1 . Drum larvae at station II were significantly lower than those at both stations I and III, and carp larvae at station II were lower than III but higher than those at I. For the species of concern (white bass, perches, sunfishes, and gizzard shad), densities at station II are similar to those at station I but significantly lower than those at station III. In terms of impact minimization for these species, therefore, it would make no difference if the intake were located in the area of station I or II. When considering freshwater drum, however, station II would, be the preferable location of the intake because drum larvae are significantly lower here than at either station I or III.

\section{Summary}

A short-term ichthyoplankton survey in the area of PINGP indicates that the total number of larvae collected in Sturgeon Lake was significantly higher than that in the river. Gizzard shad, white bass, percidae, sunfish, and carp larvae were significantly higher in the lake, while the cyprinidae (not including carp) were significantly higher in 
Table 31. Analysis of variance and Duncan's Multiple Range Test for all larvae collected at stations I-III during June 6-17, 1978

\begin{tabular}{|c|c|c|c|c|}
\hline Source & $d f$ & SS & $F$ & $P>F$ \\
\hline Station & 2 & 14.2767 & 318.55 & 0.001 \\
\hline Day & 5 & 2.1682 & 19.34 & 0.001 \\
\hline Station $x$ day & 10 & 4.0433 & 18.04 & 0.001 \\
\hline Error & 54 & 1.2101 & & \\
\hline Total (corrected) & 71 & 4.6983 & & \\
\hline \multicolumn{5}{|c|}{ Duncan's Multiple Range Test $(\alpha=0.05)$} \\
\hline \multicolumn{5}{|c|}{ Station (Mean) } \\
\hline & 7773) & $\mathrm{I}(0.4721)$ & $\mathrm{II}(0.3976)$ & \\
\hline
\end{tabular}


Table 32. Duncan's Multiple Range Test $(\alpha=0.05)$ for the larval densities (log transform) of 10 categories of $f$ ish at stations I, II, and III. Underlined stations are not significantly different.

\begin{tabular}{crcr}
\hline $\begin{array}{l}\text { Calegury } \\
\text { of fish }\end{array}$ & & & \\
\hline 1 & III $(1.1852)$ & Itation (mean) & \\
2 & I $(0.0952)$ & II $(0.1994)$ & II $(0.1621)$ \\
3 & III $(0.1406)$ & II $(0.0229)$ & II $(0.0108)$ \\
4 & II $(0.0235)$ & I $(0.0054)$ & II $(0.0037)$ \\
5 & I $(0.1914)$ & III $(0.1754)$ & II $(0.1216)$ \\
6 & II $(0.0125)$ & I $(0.0034)$ & III $(0.0030)$ \\
7 & III $(0.1562)$ & II $(0.1122)$ & I $(0.0295)$ \\
8 & I $(0.0201)$ & II $(0.0117)$ & II $(0.0082)$ \\
9 & III $(0.0080)$ & I $(0.0013)$ & II $(0.0003)$ \\
10 & II $(0.0667)$ & I $(0.0075)$ & II $(0.0030)$ \\
\hline
\end{tabular}


the river. There was no difference for drum eggs and larvae and for Catastomidae larvae between the two areas. Total egg densities at station II were not different from those at station III, but total larval densities at station III were higher than those at II or I. At station II, gizzard shad, white bass, sunfish, and percidae densities were not different from those at station I.

Relocation of the present intake does not seem justified for the purpose of minimizing impacts to gizzard shad or carp. Relocation of the intake in the main river, however, would probably minimize impacts on the white bass population.

Because the peak spawning periods of some species (particularly of sauger and walleye) were probably not included in short term 1978 survey, final decisions relative to the placement of the intake would be more reliable if based on data from a complete spawning season.

\section{Alternative location summary}

Table 33 summarizes the results of the preceding section and indicates the possible best locations of the intake for minimizing impingement and entrainment impacts. There is no conclusive evidence which demonstrates the best location for the intake. Decisions concerning intake location could vary depending upon the trophic group considered, the year, or the manner in which data are analyzed. Decisions based on individual year analysis may be different when several years are considered.

The fish electroshocking data were judged inadequate for the purpose of making reliable decisions relative to intake locations, and the 
Table 33. Summary of results relative to the best locationa of the intake for minimizing impacts to various trophic groups

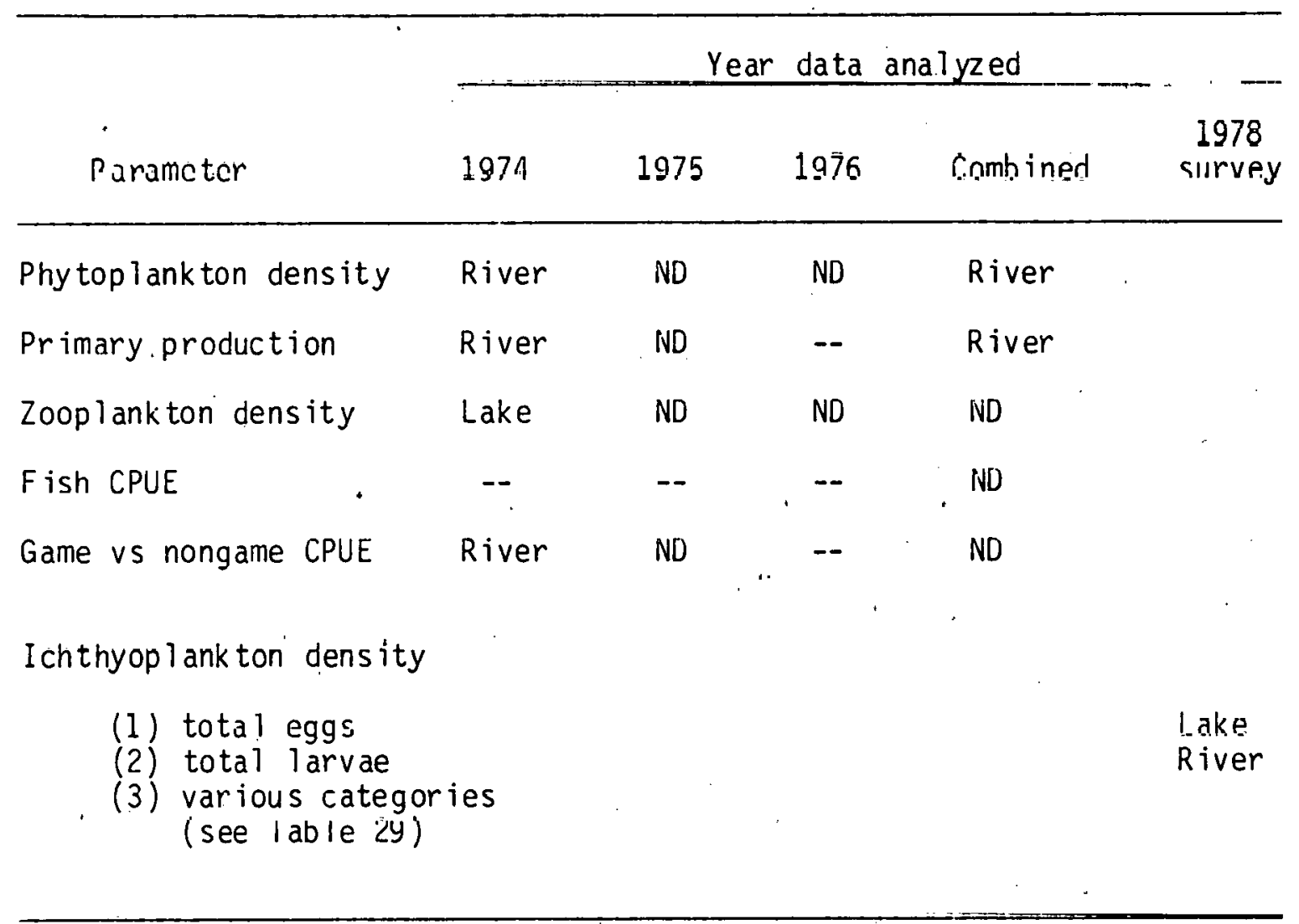

aRiver = placement of intake in river minimizes impacts; Lake = placement in lake minimizes impacts; $N U$ = no difference between lake and river. 
analysis and interpretation of the plankton data are complicated by high variability attributed to periodic high river flows. A short-term intensive ichthyoplankton survey has indicated that white bass is the only species for which relocation of the intake seems justified. A complete season of spawning data for the major fish species as well as reliable estimates of juvenile and adult populations near PINGP, however, would be desirable if this option were seriously considered.

\section{SUMMARY}

This report has addressed two of the main issues in $316(\mathrm{~b})$ demonstrations: environmental impacts associated with cooling water intake operation and location. We have conducted an independent analysis and evaluation of the Prairie Island Nuclear Power Plant 316(b) data base to illustrate assessment approaches and strategies useful in addressing these major $316(b)$ issues.

Principal causes of ecological impacts of power-plant operation are entrainment and impingement. Two major aspects of entrainment, predictions of impact on adult fish and entrainment survival of plankton, were addressed in this report. By using the "equivalent adults" technique and correcting for many of the inherent biases, the range of losses to adult stocks due to entrainment of larvae of sauger and white bass was estimated to be 2 to $28 \%$ and 2 to $72 \%$, respectively. The true impacts are probably in the upper portion of these projected ranges. The critical variables related to precise determinations of through-plant mortality of larvae are sample size (number of 
individuals of a species collected at either intake or discharge) and survival in the intake sample.

An assessment of impingement impacts was made by comparing for each of various species the fish impinged to estimates of population size. This method is probably very imprecise, however, because of the problems involved in obtaining population estimates.

A reasonable approach for evaluating the ecological effects of intake location is to compare the structure and productivity of biological communities in the intake area and other aquatic areas near the plant. In this study, this was accomplished by statistically comparing densities of plankton and fish between the intake area (Mouth of Sturgeon Lake) and the less productive Mississippi River channel. Based on this comparison, there was no conclusive evidence demonstrating the best location of the intake for minimizing ecological impacts. Decisions concerning intake locations could vary depending on the trophic group considered and the year for which data are analyzed. Biological parameters can vary significantly from year to year; therefore, decisions relative to intake location should be based on data which are representative of average years and data which are collected during periods of highest biological activity and production. 


\section{REFERENCES}

Adams, S. M., H. A. McLain, D. S. Vaughan, G. F. Cada, and K. D. Kumar. 1979. Analysis of the Prairie Island Nuclear Generating Station, intake related studies. Final Report to Minnesota Pollution Control Agency. Oak Ridge National Laboratory, Oak Ridge, Tennessee. $229 \mathrm{pp}$.

Anderson, R. A. 1975. Impingement of fishes and other organisms on the Prairie Island Plant intake traveling screens. IN Prairie Island Nuclear Generating Plant Environmental Monitoring Program for 1974. Annual Report. Northern States Power Co., Minneapolis, Minnesota.

Baker, A. L. 1975. Studies of the productivity of the phytoplankton of the Mississippi River at Prairie Island. IN Prairie Island Nuclear Generating Plant Environmental Monitoring Program for 1975. Annual Report, Northern States Power Co., Minneapolis, Minnesota.

Barnthouse, L: W., J. B. Cannon, S. W. Christensen, A. H. Eraslan, J. L. Harris, K. H. Kim, M. E. LaVerne, H. A. McLain, B. D. Murphy, R. J. Raridon, T. H. Row, R. D. Sharp, and W. Van Winkle. 1977. A selective analysis of power plant operation on the Hudson River with emphasis on the Bowline Point Generating Station. ORNL/TM-5877/V2, Chapter 5.3. Oak Ridge National Laboratory, Oak Ridge, Tennessee. 
Bjorke, H., 0. Dragesund, and 0. Ulltang. 1974. Efficiency test on four high-speed plankton samplers. pp. 183-200. IN J. H. S. Blaxter (ed.), The Early Life History of Fish, Springer-Verlag, Berlin.

Cannon, J. B., G. F. Cadà, K. K. Campbell, D. W. Lee, and A. T. Szluha. 1979. Fish protection at steam-electric power plants: Alternative screening devices. ORNL/TM-6472. Oak Ridge National Laboratory, Oak Ridge, Tennessee.

Clark, J. R., and W. Browne11. 1973. Electric power plants in the coastal zone: Environmental Issues. Am. Litteral Society Sp. Pub. No. 7. New York.

Dahiberg, M. D., and B. B. Owen. 1977. Response to NRC questions of September 26, 1977, concerning requested changes to the technical specifications, Appendix $B$, relating to closed-cycle operations at Prairie Island Nuclear Generating Plant. Docket Nos. 50-282 and 50-306, October 1977.

Ecological Analysts, Inc. 1977a. Survival of entrained ichthyoplankton and macroinvertebratès at Hudson River Power Plants. Prepared for Central Hudson Gas and Electric Corporation, Consolidated Edison Company of New York, Inc., and Orange and Rockland Utilities, Inc. $111 \mathrm{pp}$.

Ecological Analysts, Inc. 1977b. Bowline Point Generating Station entrainment and impingement studies. Chapter 4. IN 1976 Annual Report. Prepared for Orange and Rockland Utilities, Inc.

Eddy, S., and J. C. Underhill. 1974. Northern Fishes. Univ. Minnesota Press, Minneapolis. $414 \mathrm{pp}$. 
Environmental Protection Agency 1976. Development document for best technology available for the location, design, construction, and capacity of cooling water intake structures for minimizing adverse environmental impact. EPA 440/1-76/015-a, April 1976. 263 pp.

Fleiss, J. L. 1973. Statistical Methods for Rates and Proportions. John Wiley and Sons, New York. 223 pp.

Goodyear, C. P. 1978. Entrainment impact estimates using the equivalent adult approach. Tech. Rep. USFWS No. FWS-OBS-78/65. 14 pp. Gustafson, S. P., J. L. Geis, and P. J. Diedrich. 1975. Progress report on the Prairie Island fish population study. IN Prairie Island Nuclear Generating Plant Environmental Monitoring Program for 1975. Annual Report, Vol. II. Northern States Power Co., Minneapolis, Minnesota.

Horst, T. J. 1975. An assessment of impact due to entrainment of ichthyoplankton. pp. 107-118. IN S. B. Saila (ed.), Fisheries and Energy Production. D. C. Heath and Co., Lexington, Massachusells.

Kjelson, M. A. 1977. Estimating the size of juvenile fish populations in southeastern coastal-plain estuaries. pp. 71-90. IN W. Van Winkle (ed.), Assessing the Effects of Power-Plant-Induced Mortatity on Fish Populations. Pergamon Press, New York.

Kjelson, M. A., and D. R. Colby. 1977. The evaluation and use of gear efficiencies in the estimation of estuarine fish abundance. pp. 416-424. IN M. Wiley (ed.), Estuarine Processes, Volume II. Academic Press, New York. 
Leithiser, R. M., K. F. Ehrlich, and A. B. Thum. 1979. Comparison of a high volume pump and conventional plankton nets for collecting fish larvae entrained in power-plant cooling systems. J. Fish. Res. Board Can. 36:81-84.

McGroddy, P. M., and R. L. Wyman. 1977. Efficiency of nets and a new device for sampling living fish larvae. J. Fish. Res. Bd. Can. $34: 571-574$.

Murphy, G. I., and R. I. Clutter. 1972. Sampling anchovy larvae with a plankton purse seine. Fish. Bull. 70(3):789-798.

NUS Corporation. 1976. 316(b) Demonstration for the Prairie Island Nuclear Generation Plant.

Pyne, D. A. 1976. On the comparison of two binomial or poisson populations when sampling units are nonhomogeneous. Tech. Rept. No. 246. Dept. of Mathematics, The Johns Hopkins University. $23 \mathrm{pp}$.

Raj, Des. 1968. Sampling Theory. McGraw-Hill Book Co., New York. 302 pp.

Ray, S. S., R. L. Snipes, and D. A. Tomljanovich. 1976. A state-ofthe-art report on intake technologies. U.S. Environmental Protection Agency, Washington, D.C. EPA-600/7-76-020. 82 pp.

Schnack, D. 1974. On the reliability of methods for quantitative surveys of fish larvae. pp. 201-212. IN J.H.S. Blaxter (ed.), The Early Life History of Fish. Springer-Verlag, Berlin. 
Sonnichsen, J. C., W. E. Farr, and H. S. Riesbol. 1975. Fish Protective Devices: A Comopilation of Recent Designs, Concepts, and Operating Experience of Water Intakes Used in the United States. Hanford Engineering Development Laboratory. Richland, Washington. Energy Research and Development Administration. HEDL-TME 75-38 UC-79.

Swee, U. B., and H. R. McCrimmon. 1966. Reproductive biology of the carp, Cyprinus carpio L., in Lake St. Lawrence, Ontario. Trans. Am. Fish. Soc. $95(4): 372-380$.

Stone and Webster Engineering Corp. 1978. Thermal discharge analysis - Prairie Island Nuclear Generating Plant, Northern States Power Company. April 1978. Denver, Colorado.

Szluha, A. T. 1974. Zooplankton. IN Prairie Island Nuclear Generating Plant Environmental Monitoring Program for 1974. Annual Report, Northern States Power Co., Minneapolis, Minnesota.

Talmage, S. S., and C. C. Coutant. 1978. Thermal effects. J. Water Pollut. Contról Fèd. 4̇ý:1514-1553.

Vaughan, D. S., and S. B. Saila. 1976. A method for determining mortality rates using the Leslie matrix. Trans. Am. Fish. Soc. $105(3): 380-383$

Wilhm, J.L. 1967. Comparison of some diversity indices applied to populations of benthic macroinvertebrates in a stream receiving organic wastes. J. Water Pollut. Control Fed. 39:1673-1683.

Yeh, G. T. 1980. Transport and dispersion of pollutants in surface impoundments: A finite element model. ORNL-5522. Oak Ridge National Laboratory, Oak Ridge, Tennessee. 
THIS PAGE

\section{WAS INTENTIONALLY LEFT BLANK}


ORNL/TM-7412

\section{INTERNAL DISTRIBUTION}

1-5. S. M. Adams.

6-7. S. I. Auerbach

8. L. W. Barnthouse

9. G. F. Cada

10. J. B. Cannon

11. S. W. Christensen

12. C. C. Coutant

13. G. K. Eddlemond

14. S. B. Gough

15-19. S. G. Hildebrand
20-24. K. D. Kumar

25-2.9. D. S. Vaughan

30. W. Van Winkle

31-32. Central Research Library

33-42. ESD Library

43-44. Laboratory Records Department

45. Laboratory Records, ORNL-RC

46. ORNL Y-12 Technical Library

47. ORNL Patent Office

EXTERNAL DISTRIBUTION

48. R. L. Ballard, U.S. Nuclear Regulatory Commission, Washington, OC 20555

49. R. F. Berry, U.S. Fish and Wildlife Service, 316 North Robert St., St. Paul, MN 55101

50. K. E. Biesinger, U.S. Environmental Protection Agency, 6201 Congdon Boulevard, Duluth, MN 55804

51. C. W. Billups, U.S. Nuclear Regulatory Commission, Washington, DC 20555

52. J. G. Boreman, National Power Plant Team, U.S. Fish and Wildlife Service, 2.929 Plymouth Road, Ann Arbor, MI 48105

53. R. W. Brocksen, Manager, Ecological Programs, Electric Power Research Institute, P.0. Box 10412, Palo Alto, CA 94303

54. E. J. Carpenter, Marine Sciences Research Center, State University of New York, Stony Brook, NY 11794

55. J. P. Clugston, Southeast Reservoir Investigations, Clemson University, Clemson, SC 29631

56. W. J. Coppoc, Texaco, Inc., P.0. Box 509, Beacon, NY 12508

57. P. C. Cota, U.S. Nuclear Regulatory Commission, Washington, DC 20555

58. R. B. Craig, Henningson, Durham, and Richardson, 9051

Executive Park Drive, Suite 400, Knoxville, TN 37923

59. C. E. Cushing, Ecosystems Department, Battelle-Northwest Laboratories, Richland, WA 99352

60. A. A. Galli, U.S. Environmental Protection Agency, Mail Code R.D. 682,401 M. Street, S.W., Washington, DC 20460

61. J. L. Geis, Department of Natural Resources, Centennial Office BID., St. Paul, MN 55155

62. R: A. Goldstein, Electric Power Research Institute, P.0. Box 10412, Palo Alto, CA 94304

63. C. P. Goodyear, National Powerplant Team, U.S. Fish and Wildlife Service, 2929 Plymouth Road, Ann Arbor, MI 48105 
64. P. A. Hackney, Division of Forestory, Fisheries and Wildlife Development, TVA, Norris, TN 37828

65. D. H. Hamilton, Office of Health and Environmental Research, Department of Energy, Washington, DC 20545

66. C. Hickey, U.S. Nuclear Regulatory Commission, Washington, DC 20555

67. T. Horst, Environmental Engineering Division, Stone and Webster Engineering Corp., 225 Franklin St., Boston, MA 02107

68. A. L. Jensen, School of Natural Resources, University of Michigan, Ann Arbor, MI 48104

69. M. Lahtiner, Minnesota Pollution Control Agency, 1935 W. County Road B2, Rosevilie, Minnesota 55113

70. R. A. Lewis, EV-34, GTN, U.S. Department of Energy, Washington, DC 20545

71. Bernard Manowitz, Chairman, Department of Energy and Environment, Brookhaven National Laboratory, Upton, NY 11973

72. Sidney Marks, Environmental Health and Safety Research, Battelle-Pacific Northwest Laboratory, P.0. Box 999, Richland, WA 99352

73. R. P. Marshall, Battelle-Pacific Northwest Laboratory, P.0. Box 999, Richland, WA 99352

74. R. E. Martin, Department Biological Science, Tennessee Technologic University, Cookeville, TN 38501

75. H. McCammon, Director, Division of Environmental Research, Department of Energy, Washington, DC 20545

76. R. S. McGinnis, Northern States Hower Company, Minneapolis, MN 55401

77. D. McKenzie, Ecosystems Department, Battelle-Pacific Northwest Laboratory, Rich1and, WA 99352

78. G. Milburn, U.S. Environmental Protection Agency, Region V, Enforcement Division, 230 S. Dearborn St., Chicago, IL bU6U4

79. I. P. Murarka, Electric Power Research Institute, P.0. Box $1041 \%$, Palo Alto, CA 94303

Bก. W. S. Osburn, Jr, Division of Ecolngical Research, Office of Health and Environmental Research, Department of Energy, Washington, DC 20545

81. R. L. Patterson, School of Natural Resources, University of Michigan, Ann Arbor, MI 38104

82. Ralph Perhac, Electric Power Research Institute, P.0, Box 10412, Palo Alto, CA 94304

83. John Porter, Director Environmental Sciences Section, Savannah River Laboratory, Aiken, SC 29801

84. H. R. Preston, U.S. Environmental Protection Agency, 303 Methodist Bivd., 11 th and Chapline Streets, Wheeling, WV 26003

85. P. J. Rago, National Power Plant Team, U.S. Fish and Wildlife Service, 2929 Plymouth Road, Ann Arbor, MI 48105 
86. W. L. Redmon, U.S. Environmental Protection Agency, Region V, 230 S. Dearborn St., Chicago, IL 60604

87. P. G. Risser, Department of Botany and Microbiology, University of Oklahoma, Norman, Oklahoma 73019

88. R. E. Rowland, Director, Radiological and Environmental Research Division, Argonne National Laboratory, 9700 South Cass Ave., Argonne, ILL 60439

89. S. Saila, Department of Zoology, University of Rhode Island, Kingston, RI 02881

90. W. E. Schaaf, Atlantic Estuarine Fisheries Center, National Marine Fisheries Service, Beaufort, NC 28516

91. R. K. Sharma, Argonne National Laboratory, 9700 S. Cass Ave., Argonne, IL 60439

92. G. R. Shepherd, Department of Energy, Rm 4G-052, MS 4G-085, Forestal Building, Washington, DC 20545

93. S. A. Spigarelli, Argonne National Laboratory, 9700 S. Cass Ave., Argonne, IL 60439

94. G. Swartzman, Center for Quantitative Science, University of Washington, Seattle, WA 98195

95. J. M. Thomas, Ecosystems Department, Battelle-Pacific Northwest Laboratory, Richland, WA 99352

96. C. Voightlander, Tennessee Valley Authority, Norris, TN 37828

97. R. H. Waring, Department of Forest Science, Oregon State University, Corvallis, OR 97331

98. R. L. Watters, Office of Health and Environmental Research, Department of Energy, Washington, DC 20545

99. R. W. Wood, Office of Health and Environmental Research, B1dg. GTN, Germantown, MD 20767

100. Office of Assistant Manager for Energy Research and Development, Department of Energy, Oak Ridge Operations, Oak Ridge, TN 37830

101-127. Technical Information Center, Oak Ridge, TN 37830 